\section{$D 0 k / P C / 90045=-76$}

QUARTERLY REPORT

Report Period

April 1, 1992 to June 30, 1992
DOE/PC/90045--T6

DE93 007561

FOR

\title{
CATALYST AND PROCESS DEVELOPMENT FOR SYNTHESIS GAS CONVERSION TO ISOBUTYLENE
}

Submitted to

United States Department of Energy Pittsburgh Energy Technology Center

July 27, 1992

(Approved September 2, 1992)

by

Rayford G. Anthony and Aydin Akgerman

Kinetics, Catalysis and Reaction Engineering Laboratory

Department of Chemical Engineering

Texas A\&M University

College Station, TX 77843-3122

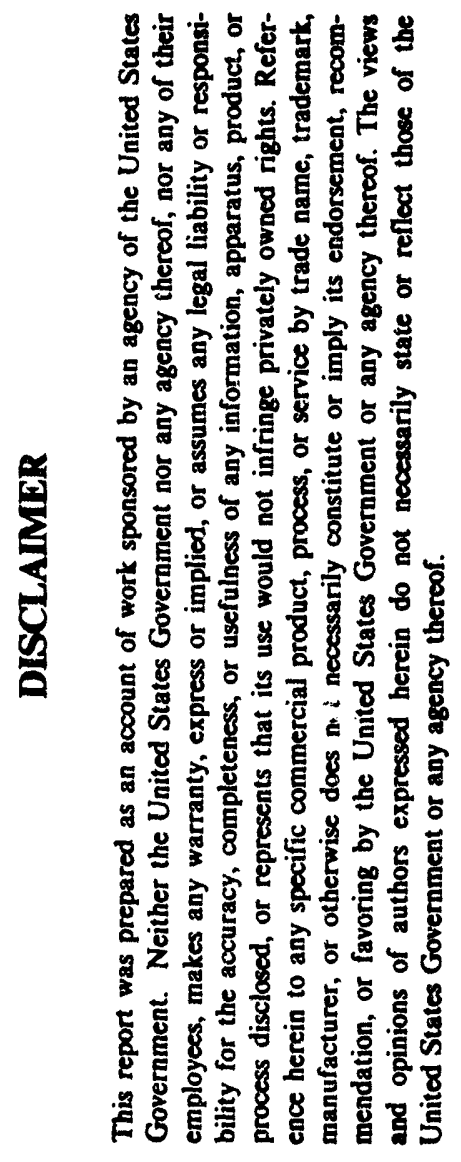

UNDER DOE CONTRACT NO. DE-AC22-90PC90045

(Texas A\&M Research Foundation Project No. 6722)
MASTER

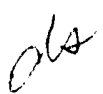




\section{CATALYST AND PROCESS DEVELOPMENT FOR \\ SYNTHESIS GAS CONVERSION TO ISOBUTYLENE}

DOE CONTRACT NO. 90PC90045

TEXAS A\&M RESEARCH FOUNDATION PROJECT NO. 6722

Quarterly Report

Report Period: 4/1/92 to $6 / 30 / 92$

\section{PROJECT OBJECTIVES}

The objectives of this project are to develop a new catalyst, the kinetics for this catalyst, reactor models for trickle bed, slurry and fixed bed reactors, and simulate the performance of fixed bed trickle flow reactors, slurry flow reactors, and fixed bed gas phase reactors for conversion of a hydrogen lean synthesis gas to isobutylene.

\section{JUSTIFICATION FOR THE PROJECT}

Isobutylene is a key reactant in the synthesis of methyl tertiary butyl ether (MTBE) and of isooctanes. MTBE and isooctanes are nigh octane fuels used to blend with low octane gasolines to raise the octane number required for modem automobiles. The production of these two key octane boosters is limited by the supply of isobutylene. MTBE when used as an octane enhancer also decreases the amount of pollutants emitted from the exhaust of an automobile engine.

Hydrogen-rich synthesis gas has been converted to isobutylene using a zirconia based catalyst. However, the produstivity and yields are low, and the ability of the catalyst to convert a hydrogen-lean synthesis gas to isobutylene with high productivity and yields, and without excessive deactivation is unknown.

\section{PROPOSED PROCESS}

A hydrogen-lean synthesis gas with a ratio of $\mathrm{H}_{2} / \mathrm{CO}$ of 0.5 to 1.0 is produced from the gasification of coal, lignite, or biomass. This hydrogen-lean synthesis gas can be processed in a "shift reactor" with steam to convert the hydrogen-lean synthesis gas to a hydrogen-rich synthesis gas. But, this processing step is inefficient and consumes considerable energy. If the hydrogen-lean synthesis gas could be converted directly to isobutylene, a significant increase in 
process efficiency will be the result. We envision a reactor system and catalyst that will selectively and efficiently convert hydrogen-lean synthesis gas to isobutylene. The catalyst, based on past work published in the literature, wili most likely be zirconia or thoria based, and will contain components to promote the water-gas shift reaction and increase the selectivity of isobutylene.

\section{GOALS FOR THE QUARTER}

The goals for the quarter include 1) Filing the necessary reports, 2) Completing the experiments on sodium impregnated zirconia. 3) Conducting experiments with the AE MSBTR 900 on a thoria-zirconia prepared hydrothermally. 4) Continue work to synthesize a zirconate with a layered structure. The objective is to determine if changing the crystal structure will affect the catalysts activity and selectivity. 5) Continue the microkinetic modelling. This approach is finally beginning to produce some useful results. 6) Continue the empirical modelling.

\section{ACCOMPLISHMENTS FOR THE QUARTER}

\section{Filing of necessary reports}

The quarterly report for the period of January 1, 1992 to March 31, 1992 was filed and approved. Monthly reports for March, April, and May were also filed.

\section{Microkinetic Model}

Table 1 presents a calculated product distribution using the microkinetic model and the reaction sequence presented in Table 1 of the last quarterly. We are predicting the production of more isobutylene than is being produced experimentally. We believe that further analysis and changes required to match the experimental data will lead to the design of improved catalysts.

\section{Experimental Program}

Substantial progress has been made in the synthesis of new catalysts. Zirconia has been prepared by precipitation with ammonium hydroxide or sodium hydroxide from zirconyl nitrate, by a modified sol gel method, and by a hydrothermal method. Catalyst prepared by these methods are labelled as ppt, sol gel and HT, respectively. In one case, a hydrous sodium zirconium oxide prepared by sol gel method was ion exchanged to produce a cesium/zirconia catalyst. This catalysts as labelled as sol gel/IE. 
A catalyst with $2 \%$ Th on zirconia was prepared by precipitating zirconia followed by impregnating with thorium nitrate, drying and calcining at $500{ }^{\circ} \mathrm{C}$ for 5 hours. A $10 \%$ Th on zirconia was prepared by a hydrothermal method. The XRD pattern of this catalyst indicated a tetragonal structure, which did not change on calcination. Zirconia was prepared with $1.6 \%$ $\mathrm{Na}$ by using sodium hydroxide and ammonium hydroxide to precipitate zirconyl nitrate. Zirconia and zirconia/silica with a molar ratio of $4: 1 \mathrm{Zr}$ :Si were prepared using a modified sol gel procedure. A $1.6 \mathrm{wt} \% \mathrm{Na} / 10.3 \mathrm{wt} \% \mathrm{Ti} / \mathrm{ZrO}_{2}$ prepared hydrothermally had a tetragonal structure. The $\mathrm{HZrO}_{2} 0.25 \mathrm{Si}(\mathrm{HCl})$ as prepared was amorphous and after calcination at $500^{\circ} \mathrm{C}$ the structure was tetragonal. The remaining catalysts were monoclinic after calcining them at $500{ }^{\circ} \mathrm{C}$ for 5 hours. Data currently available on the surface areas and XRD patterns are presented in Table 2. The XRD powder patterns are also presented in the appendix.

Figure 1 shows a comparison at $400{ }^{\circ} \mathrm{C}$ of catalytic activities for zirconia prepared by precipitation using ammonium hydroxide, zirconia with $1.6 \%$ sodium prepared by coprecipitation of zirconyl nitrate with sodium hydroxide and ammonium hydroxide, and a 1.6 wt\% sodium $10.3 \mathrm{wt} \%$ titanium/zirconia with a tetragonal structure prepared by hydrothermal synthesis. The $1.6 \% \mathrm{Na}$ on zirconia is more active than zirconia, which is more active than the $1.6 \% \mathrm{Na}: 10.3 \% \mathrm{Ti}$ on zirconia. The product from the latter catalysts contain $31.2 \% \mathrm{i}-\mathrm{C}_{4} \mathrm{~s}$ and no linear $\mathrm{C}_{4}$ s. The activities of these catalysts are raniked as $1.6 \% \mathrm{Na} / \mathrm{ZrO}_{2}(\mathrm{ppt})>\mathrm{ZrO}_{2}(\mathrm{ppt})$ $>1.6 \% \mathrm{Na10} 0.3 \% \mathrm{Ti} / \mathrm{ZrO}_{2}$.

Figure 2 shows the fit of the data for a $1: 2 \mathrm{H}_{2}: \mathrm{CO}$ feed at $95 \mathrm{~atm}$ and the rate equations for $\mathrm{CO}$ consumption for the $1.6 \% \mathrm{Na} / \mathrm{ZrO}_{2}$ and $\mathrm{ZrO}_{2}$. The inhibition of the rate by $\mathrm{CO}_{2}$ and the overall effect of pressure of 1.5 order is illustrated. The curves in Figure 2 were generated by integrating the rate equation for a plug flow reactor, and assuming the stoichiometry such that 0.5 moles of hydrogen were consumed per mole of $\mathrm{CO}$ consumed and 0.5 moles of $\mathrm{CO}_{2}$ were produced per mole of $\mathrm{CO}$ consumed, i.e.

$$
\begin{gathered}
2 \mathrm{n} \mathrm{CO}+\mathrm{n} \mathrm{H}_{2}=\mathrm{C}_{\mathrm{n}} \mathrm{H}_{2 \mathrm{a}}+\mathrm{nCO}_{2} \\
\text { or } \\
\mathrm{CO}+0.5 \mathrm{H}_{2}=1 / 2 \mathrm{n}_{\mathrm{n}} \mathrm{H}_{2 \mathrm{n}}+0.5 \mathrm{CO}_{2}
\end{gathered}
$$

Utilizing the rate equation for $\mathrm{CO}$ consumption is a useful way to compare the activities of various catalysts in terms of kinetic expressions. Because of the complexity of the reactions 
occurring to produce hydrocarbons, a good estimate of the activation energy has not been obtained.

Figure 3 shows a comparison at $450{ }^{\circ} \mathrm{C}$ of the catalytic activities of $2 \mathrm{wt} \% \mathrm{Th} / \mathrm{ZrO}_{2}$ prepared by precipitating the $\mathrm{ZrO}_{2}$ to form a gel and impregnating with thorium nitrate, a 10 $w t \% \mathrm{Th} / \mathrm{ZrO}_{2}$ prepared hydrothermally, $\mathrm{HZrO}-\mathrm{HCl} 0.25 \mathrm{Si}$ prepared by sol gel and zirconia prepared by precipitation. The catalysts were washed with water and acetone, dried and calcined at $500^{\circ} \mathrm{C}$. The activities are ranked as $2 \% \mathrm{Th} / \mathrm{ZrO}_{2}>\mathrm{ZrO}{ }_{2}>10 \% \mathrm{Th} / \mathrm{ZrO}{ }_{2} \geq \mathrm{HZrO}-\mathrm{HCl}$ $0.25 \mathrm{Si}$.

Figure 4 illustrates the effect of temperature on the mean rate of consumption of $\mathrm{CO}$ for catalysts studied at more than one temperature. The slopes for the lines plotted in Figure 4 are proportional to activation energies, which are changing for the different catalysts. However, additional data are required to determine if a variation in activation energies is statistically valid. However, the plot is useful for comparing catalyst activities and indicates the $10 \% \mathrm{Th} / \mathrm{ZrO}_{2}, \mathrm{HT}$ is as active as zirconia prepared by precipitation.

The overall ranking of catalytic activities is $2 \% \mathrm{Th} / \mathrm{ZrO}_{2}>1.6 \% \mathrm{Na} / \mathrm{ZrO}_{2}>\mathrm{ZrO}_{2}$ (by ppt.) $\geq 10 \% \mathrm{Th} / \mathrm{ZrO}_{2}$ (by hydrothermal) $\geq \mathrm{HZrO}-\mathrm{HCl} 0.25 \mathrm{Si}$ (by sol gel) $>1.6 \% \mathrm{Na} 10.3 \%$ $\mathrm{Ti} / \mathrm{ZrO}_{2}$. The data for the different temperatures were combined by using zirconia prepared by precipitation as the reference catalyst for the two temperature ranges. Differences in these catalysts are due to the method of preparation, and the type and amount of additive.

A Cs/ $\mathrm{ZrSi}_{0.25}$ with $4.5 \% \mathrm{Cs}$ was evaluated and found to have an activity less than the above list, and the product distribution was predominately methane. Table 3 presents the data for this catalyst. The support used in the preparation of the cesium catalysts was the prepared using the sol gel method, and is the $\mathrm{HZrO}_{2} \mathrm{Si}_{0.25} \mathrm{O}_{2}$ discussed in the previous paragraph. Hydrocarbon distribution for the sol gel catalyst is presented in Table 4.

Isobutylene yields for all of the catalysts were on the order of 10 to $25 \mathrm{wt} \%$ of the total hydrocarbons produced. Hence, improvement in the activities for converting $\mathrm{CO}$ to hydrocarbons and an increase in the selective to isobutylene will result in a higher production rate of isobutylene.

Figures 5 through 8 show the rates of production of isobutylene and total hydrocarbons. These figures show that the rate of production of isobutylene and hydrocarbons decrease as the 
$\mathrm{CO}$ conversion increases because of the longer space times (Figures 1 and 3 ) required to increase the $\mathrm{CO}$ conversion. A major goal in isosynthesis is to obtain a catalyst of sufficient activity to operate the reactor at low temperatures and low pressures with high $\mathrm{CO}$ conversions and high selectivities and production rates of isobutylene.

Tabies 3 through 10 present hydrocarbon distributions and activity data obtained for some of the catalysts, and Figures 9 through 13 present the trends obtained for sodium titanium zirconia. Figure 9 illustrates the effect of pressure and space time on the conversion of $\mathrm{CO}$. At a constant pressure the conversion increases with increase in space time, which is to be expected. However, the production rates will decrease substantially because of the reduction of space velocity required to obtain the long space times. Figure 10 illustrates the increase in methane production with an increase in pressure. Isobutylene production rate has not changed substantially for pressures above $50 \mathrm{~atm}$, but the production of methane for this catalyst increases substantially. For a space time of 60 seconds Figure 11 illustrates the continual increase in isobutylene with the increase in pressure up to $70 \mathrm{~atm}$. Above $70 \mathrm{~atm}$, only methane and $\mathrm{C}_{s}^{+}$ are increasing. Figures 12 and 13 compare the performance of the $\mathrm{ZrO}_{2}$ (ppt.), $1.6 \% \mathrm{Na} / \mathrm{Zr}_{2}$ (ppt) and the $1.6 \%, 10.3 \% \mathrm{Ti} / \mathrm{ZrO}_{2}(\mathrm{HT})$. The effect of the $\mathrm{Ti}$ in the catalyst is to increase the production of iso compounds, and to decrease the amount of $\mathrm{C}_{5}^{+}$while increasing the production rate of methane.

Figures 14 and 15 illustrate the relationship between space velocity and space time. Space time for a constant density system is the same as residence time. Whereas, space velocity is the flow rate at $\mathrm{O}^{\circ} \mathrm{C}$ and $1 \mathrm{~atm}$ divided by the volume of catalyst. Hence, space velocity is a measure of catalyst utilization. The kinetics howe ser are controlled by the residence time which is closely approximated for this system by the space time.

In addition to the XRD powder patterns presented in the Appendix, figures illustrating typical temperature profiles in the tubular reactors are presented. The catalyst is loaded in the isothermal region of the temperature profile.

\section{SIGNIFICANT ACCOMPLISHMENTS AND CONCLUSIONS}

A rate equation for carbon monoxide consumption showing first order in $\mathrm{CO}$ and 0.5 order in hydrogen indicates the rate controlling step involves dissociated hydrogen. The inhibition of the rate with carbon dioxide is also shown. Examination of the hydrocarbon 
distributions indicates a see-saw effect with the $\mathrm{C}_{4} \mathrm{~s}$ representing the fulcrum and methane and $\mathrm{C}_{5}{ }^{+}$the end points. The shift in the distributions tends to be towards the $\mathrm{C}_{5}{ }^{+}$for high pressures and long residence times. This distribution can be shifted by incorporating Ti into the catalysts, but the optimum amount of $\mathrm{Ti}$ needs to be determined. The sol gel method of preparing the catalysts tends to produce a less active catalyst than by precipitation of a zirconyl salt. The most active catalyst contained approximately $2 \% \mathrm{Th} / \mathrm{ZrO}_{2}$.

\section{GOALS FOR THE NEXT QUARTER}

The goals for the next quarter include: 1. Preparation of the presentation and manuscript for the DOE Contractors Meeting in September. 2. Evaluation of an alumina/zirconia catalyst prepared by a revised modified sol gel method. We anticipate an increase in the surface area and activity using this method of preparation. 3. Prepare a sodium/titanium/thorium/zirconia catalysts using precipitation with sodium/titanium/thorium weight percents of $0.8,2$ and 2 on zirconia. Also, prepare a catalyst with the same composition using the sol gel and hydrothermal method. 4. Attempt to stabilize the high $\mathrm{d}_{0}$-zirconate to maintain the high surface area of the material in the as prepared state. 5. Evaluate the catalytic activity of the new catalytic materials.

\section{WORK SCHEDULE STATUS REPORT}

The work schedule status report is attached. Significant progress is shown on Tasks 1,2 and 3 with some progress on Tasks 4 and 5 . 
Table 1. Simulation of Production Distribution Using the Microkinetic Model

For Zirconia (sol gel)

(50 atm., $698 \mathrm{~K}, \tau=70 \mathrm{~s}$, Space vel. $=1006 \mathrm{~h}^{-1}$ )

\begin{tabular}{|c|c|c|}
\hline \multirow{2}{*}{ Component } & \multicolumn{2}{|c|}{ Mole Fractions } \\
\cline { 2 - 3 } & Experimental & Model \\
\hline $\mathrm{CO}_{2}$ & $3.23 \times 10^{-2}$ & $1.07 \times 10^{-2}$ \\
\hline $\mathrm{CH}_{4}$ & $7.44 \times 10^{-3}$ & $6.00 \times 10^{-3}$ \\
\hline ethane & $3.29 \times 10^{-4}$ & $4.49 \times 10^{-8}$ \\
\hline ethylene & $1.26 \times 10^{-3}$ & $7.06 \times 10^{-6}$ \\
\hline propane & $2.73 \times 10^{-4}$ & $4.48 \times 10^{-8}$ \\
\hline propylene & $3.48 \times 10^{-4}$ & $2.2 \times 10^{-6}$ \\
\hline isobutylene & $5.31 \times 10^{-4}$ & $37.8 \times 10^{-4}$ \\
\hline 2-butene & $5.58 \times 10^{-4}$ & $2.80 \times 10^{4}$ \\
\hline 1-butene & $6.1 \times 10^{-5}$ & $1.37 \times 10^{-5}$ \\
\hline n-butane & $2.45 \times 10^{-4}$ & $1.74 \times 10^{-6}$ \\
\hline isobutane & $8.57 \times 10^{-4}$ & $6.31 \times 10^{-4}$ \\
\hline
\end{tabular}


Table 2. Surtace Areas and XRD Pattern

\begin{tabular}{|c|c|c|c|c|}
\hline Catalyst & $\begin{array}{c}\text { Surtace Area } \\
\mathrm{m}^{2} / \mathrm{g} \\
\text { Before Reaction } \\
\text { cal. at } 500^{\circ} \mathrm{C} \\
\end{array}$ & $\begin{array}{l}\text { Surface Area } \\
\mathrm{m}^{2} / \mathrm{g} \\
\text { After Reaction }\end{array}$ & $\begin{array}{c}\text { XRD Pattem } \\
\text { Before Reaction } \\
\text { calcined } 500^{\circ} \mathrm{C}\end{array}$ & $\begin{array}{l}\text { XRD Pattern } \\
\text { After Reaction }\end{array}$ \\
\hline $\begin{array}{l}2 \% \text { Th/ZrO, } \\
\text { (ppti) }\end{array}$ & N/A & 83 & N/A & $N / A$ \\
\hline $\begin{array}{l}1.6 \% \mathrm{Na} / \mathrm{ZrO}_{2} \\
\text { (ppt) }\end{array}$ & 58 & N/A & Monoclinic & N/A \\
\hline $\mathrm{ZrO}_{2}(\mathrm{ppt})$ & 55 & 42 & Monoclinic & Monoclinic \\
\hline $\begin{array}{c}10 \% \mathrm{Th} / \mathrm{ZO}_{2} \\
\text { (Hydrothermal) }\end{array}$ & N/A & N/A & Monoclinic & N/A \\
\hline $\begin{array}{c}\mathrm{Zr}_{0.0 .} \mathrm{Si}_{0.2} \mathrm{O}_{2} \\
\text { (HCl-sol gel) }\end{array}$ & N/A & 73 & Tetragonal & N/A \\
\hline $\begin{array}{c}1.6 \% \mathrm{Na10.3 \% TVZr} \\
\mathrm{O}_{2}(\mathrm{HT}) \\
\end{array}$ & 88 & N/A & Tetragonal & N/A \\
\hline $\mathrm{Si}_{0.2} \mathrm{Zr}_{0.8} \mathrm{O}_{2}(\mathrm{HT})$ & 128 & N/A & Tetragonal & N/A \\
\hline $\begin{array}{c}4.5 \% \mathrm{Cs} / \mathrm{Si}_{0.2} \mathrm{Zr}_{0.8} \mathrm{O}_{2} \\
\text { (sol geV/IE) }\end{array}$ & $\begin{array}{l}216 \text { (prior to } \\
\text { calcination) }\end{array}$ & N/A & $\begin{array}{c}\text { Amorphous } \\
\text { (prior to } \\
\text { calcination) } \\
\end{array}$ & N/A \\
\hline$\underset{\text { (sol gel) }}{\mathrm{ZrO}_{2}}$ & 92 & N/A & Tetragonal & N/A \\
\hline
\end{tabular}

XRD Powder Patterns are presented in the appendix. 
Table 3. Activity Data and Product Distribution for Cs- $\mathrm{Zr}-\mathrm{Si}_{0.26}$ Prepared by Ion Exchange

\begin{tabular}{|c|c|}
\hline Catalyst ID & $\mathrm{Cs}-\mathrm{Zr}-\mathrm{Si}_{0.25}$ \\
\hline Catalyst volume (cc) & 3.6 \\
\hline Catalyst weight (g) & 5.27 \\
\hline $\mathrm{CO} / \mathrm{H}_{2}$ molar ratio & 1 \\
\hline Reactant flow rate (cc/min STP) & 226.6 \\
\hline Average reaction temperature $\left({ }^{\circ} \mathrm{C}\right)$ & $445(718 \mathrm{~K})$ \\
\hline Reaction pressure (psig) & $1008(68.6 \mathrm{~atm})$ \\
\hline $\begin{array}{l}\text { Space time, volume of catalyst/volumetric flow } \\
\text { rate of feed at reaction condition, (second) }\end{array}$ & Space vel. $\stackrel{24.8}{=} 3840 \mathrm{~h}^{-1}$ \\
\hline CO conversion $(\%)$ & 4.7 \\
\hline \multicolumn{2}{|c|}{ Product distribution (wt \%) } \\
\hline Carbon dioxide & 49.27 \\
\hline Dimethyletîar & 0.665 \\
\hline Methanol & 0 \\
\hline Hydrocarbons & 50.07 \\
\hline Hydrocarbon production rate, $\mathrm{g} / \mathrm{hr} / \mathrm{kg}$ catalyst & 37.9 \\
\hline \multicolumn{2}{|c|}{ Hydrocarbon distribution (wt\%) } \\
\hline Metharie & 40.68 \\
\hline Ethylene & 2.937 \\
\hline Ethane & 11.47 \\
\hline Propane & 3.605 \\
\hline Propylene & 3.309 \\
\hline iso-Butane & 1.009 \\
\hline n-Butane & 2.557 \\
\hline 1-Butene & 1.984 \\
\hline iso-Butene & 1.886 \\
\hline trans-Butene & 1.526 \\
\hline cis-Butene & 0.894 \\
\hline $\mathrm{C}_{6+}$ & 28.15 \\
\hline
\end{tabular}

Space Velocity is calculated at $0^{\circ} \mathrm{C}$ and 1 atm. 
Table 4. Activity and Product Distributions for $\mathrm{Si}_{0,25} \mathrm{ZrO}_{2.5}$ (HC.l-sol gell)

\begin{tabular}{|c|c|}
\hline Catalyst ID & $\mathrm{Zr}_{2} \mathrm{Si}_{2} \mathrm{O}_{2}$ \\
\hline Catalyst volume (cc) & 4.6 \\
\hline Catalyst weight $(g)$ & 4.88 \\
\hline $\mathrm{CO} / \mathrm{H}_{2}$ molar ratio & 1 \\
\hline Reactant flow rate (cc/min STP) & 270.0 \\
\hline Average reaction temperature $\left({ }^{\circ} \mathrm{C}\right)$ & $450(723 \mathrm{~K})$ \\
\hline Reaction pressure (psig) & $1013(70 \mathrm{~atm})$ \\
\hline $\begin{array}{l}\text { Space time, volume of catalyst/volumetric flow } \\
\text { rate of feed at reaction condition, (second) }\end{array}$ & $\begin{array}{c}26.05 \\
\text { Space Vel } l^{\circ}=3649 \mathrm{~h}^{-1}\end{array}$ \\
\hline CO conversion (\%) & 13.38 \\
\hline \multicolumn{2}{|c|}{ Product distribution (wt\%) } \\
\hline Carbon dioxide & 66.43 \\
\hline Dimethylether & 0.010 \\
\hline Methanol & 0.004 \\
\hline Hydrocarbons & 33.56 \\
\hline Hydrocarbon production rate, $\mathrm{g} / \mathrm{hr} / \mathrm{kg}$ catalyst & 93.2 \\
\hline \multicolumn{2}{|c|}{ Hydrocarbon distribution (wt \%) } \\
\hline Methane & 9.839 \\
\hline Ethylene & 2.209 \\
\hline Ethane & 1.635 \\
\hline Propane & 3.396 \\
\hline Propylene & 2.933 \\
\hline iso-Butane & 4.201 \\
\hline n-Butane & 0 \\
\hline 1-Butene & 0.830 \\
\hline iso-Butene & 12.62 \\
\hline trans-Butene & 0.945 \\
\hline cis-Butene & 0.671 \\
\hline $\mathrm{C}_{5}$ & 60.73 \\
\hline
\end{tabular}

Space Velocity is calculated at $0^{\circ} \mathrm{C}$ and $1 \mathrm{~atm}$. 


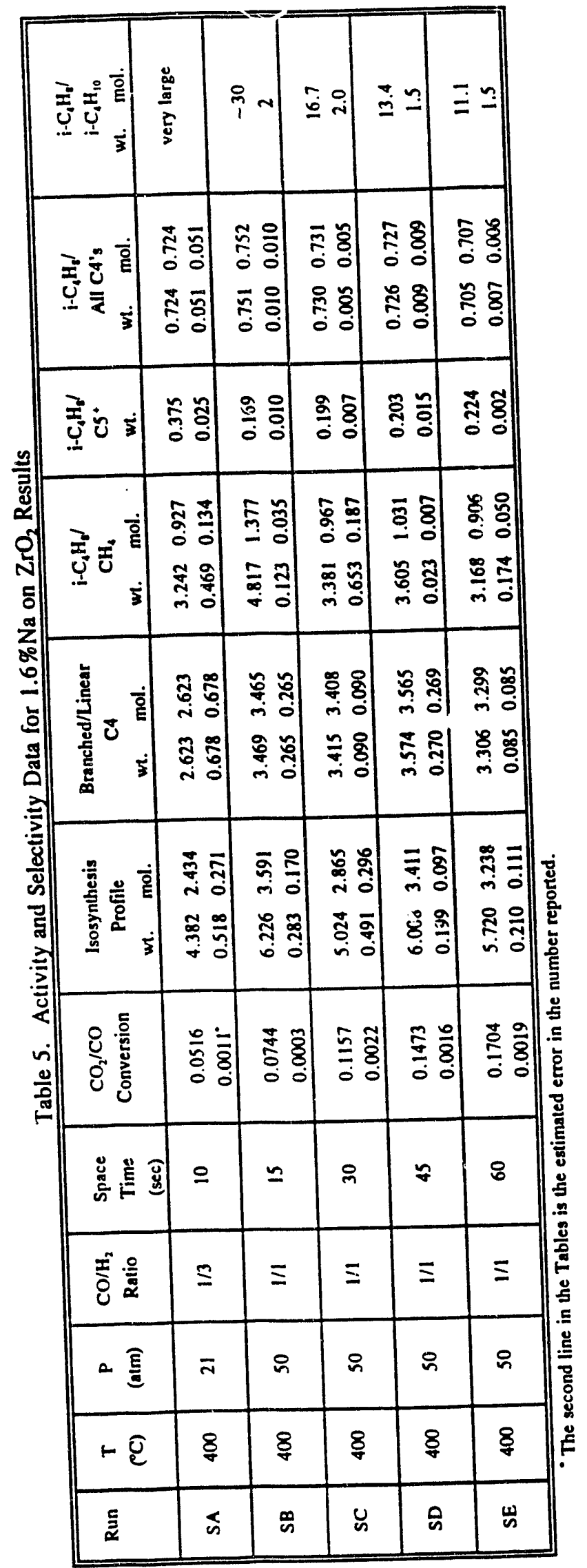




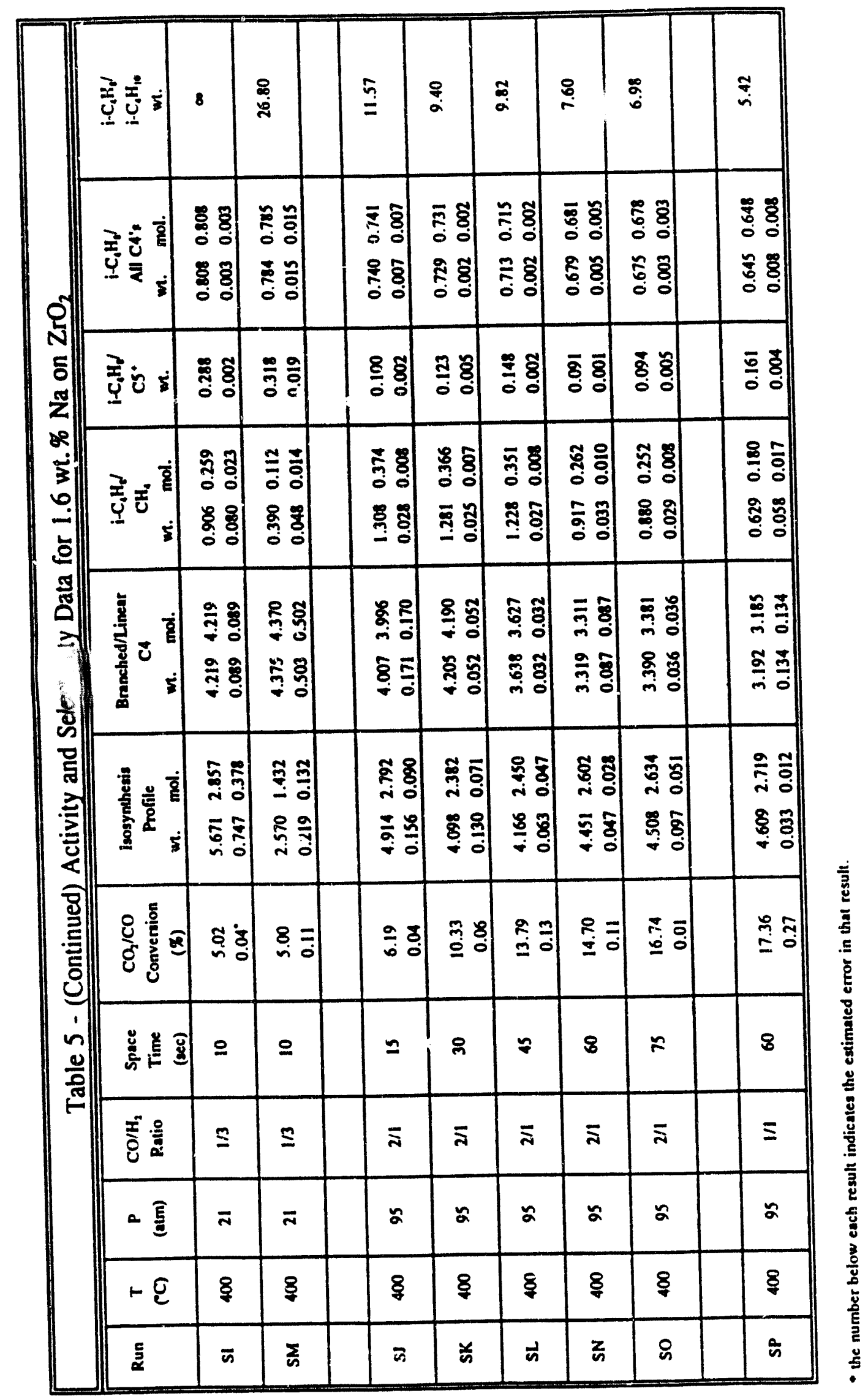




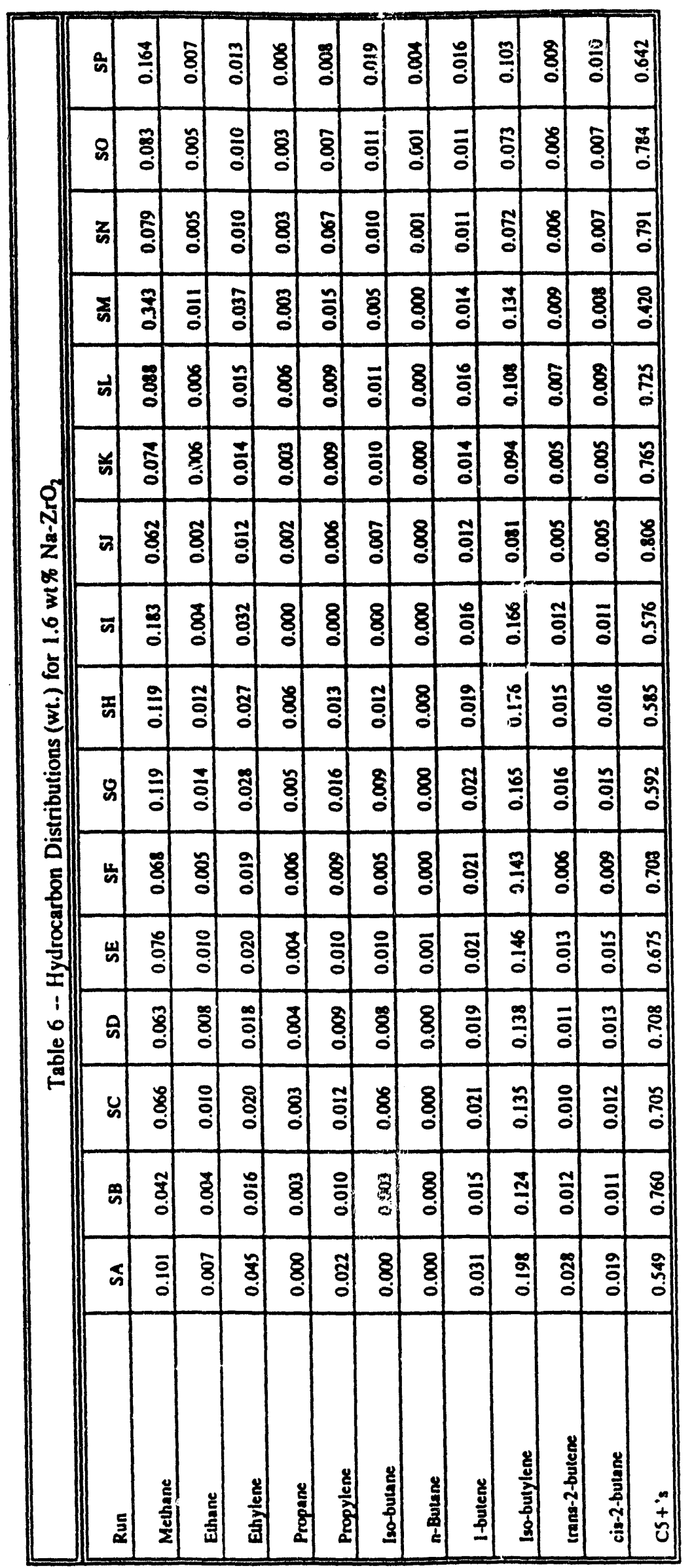




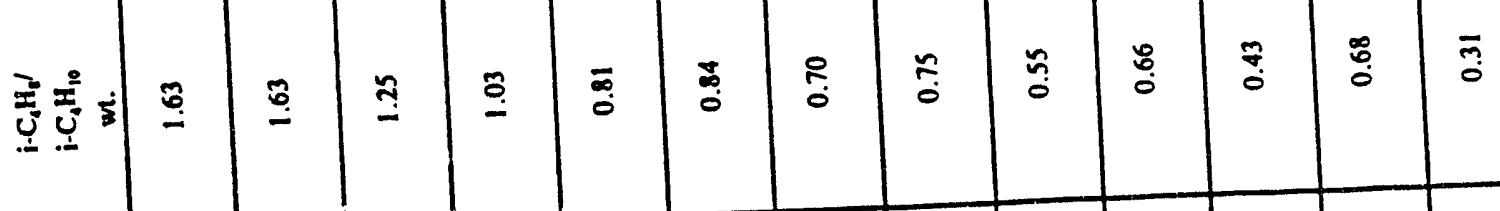

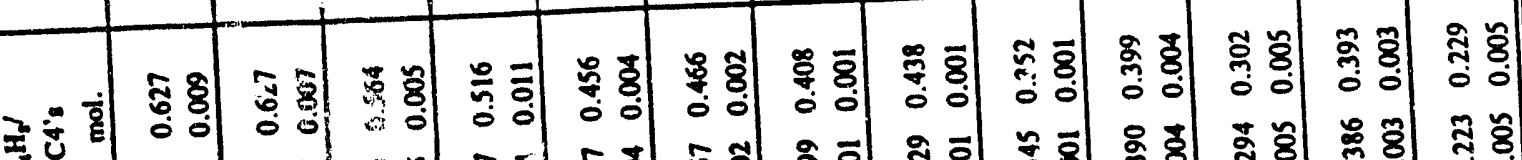

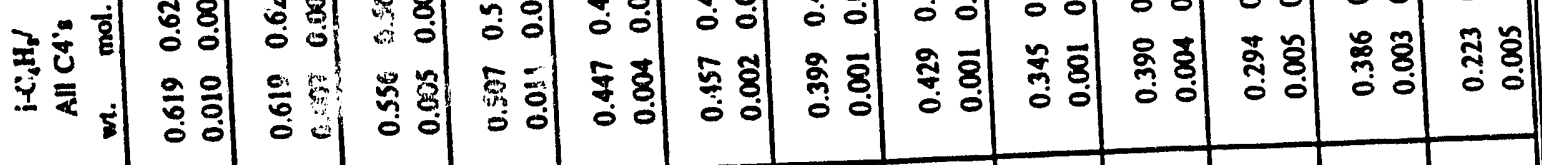

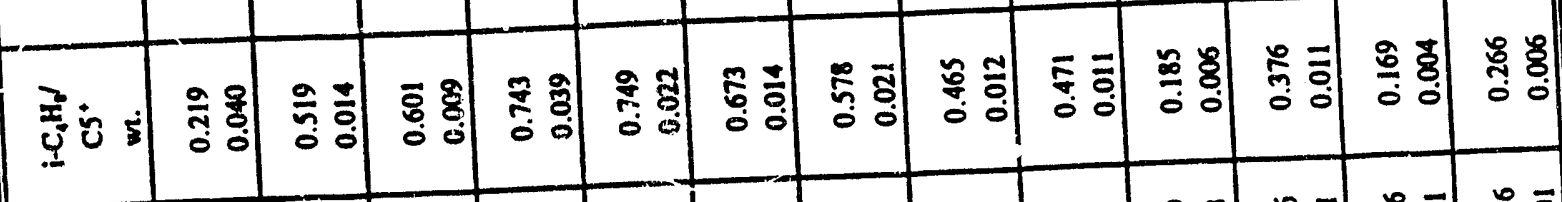

送

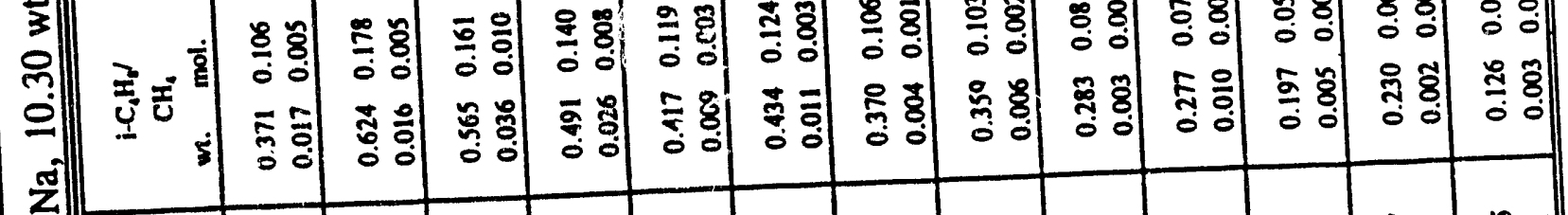

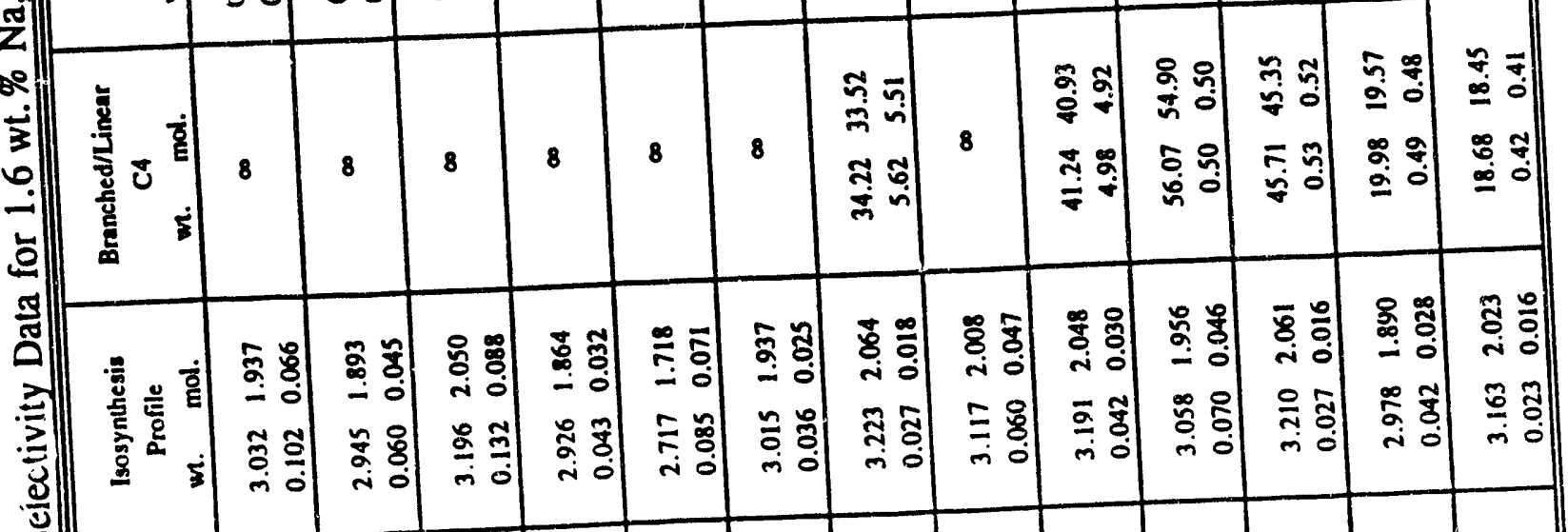

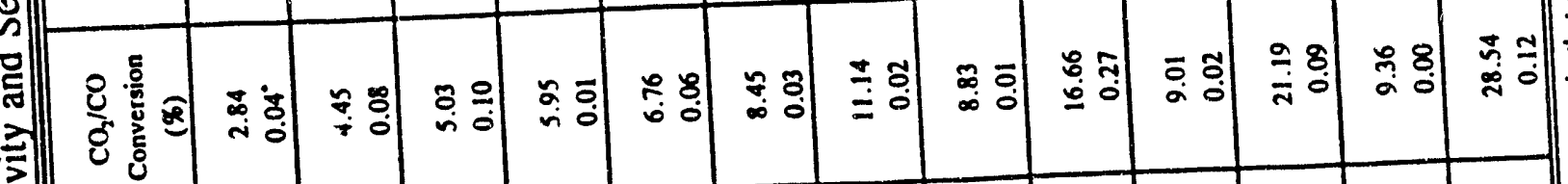

\begin{tabular}{||l|l|l|l|l|l|l|l|l|l|l|l|l|l|}
\hline \\
\hline \\
\hline
\end{tabular}


引

굴

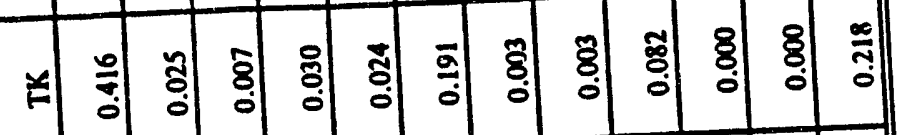

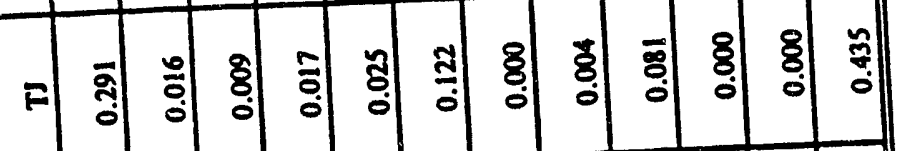

占 $=$ F

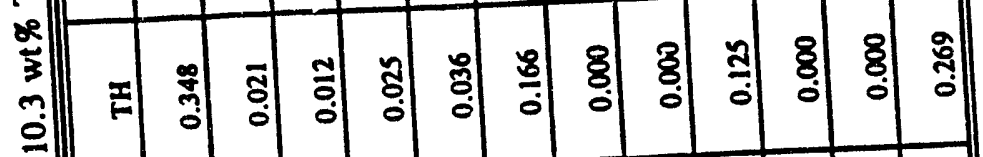

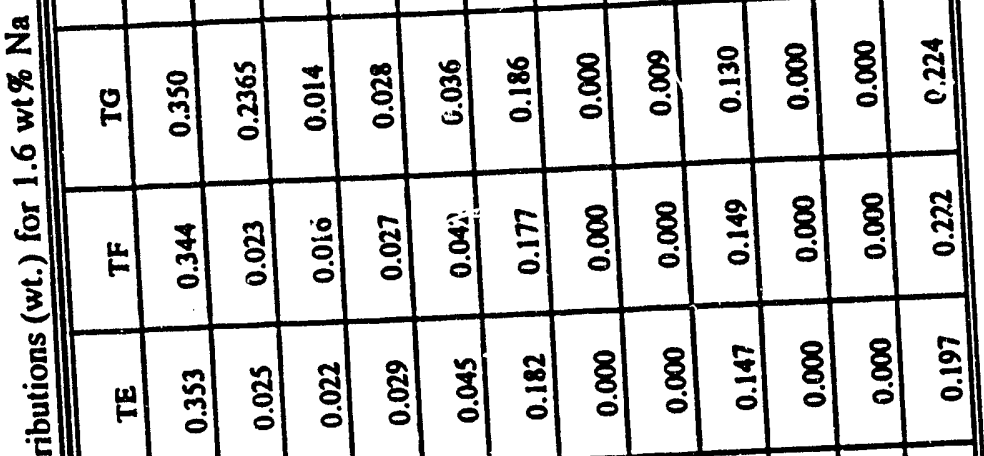

응

은

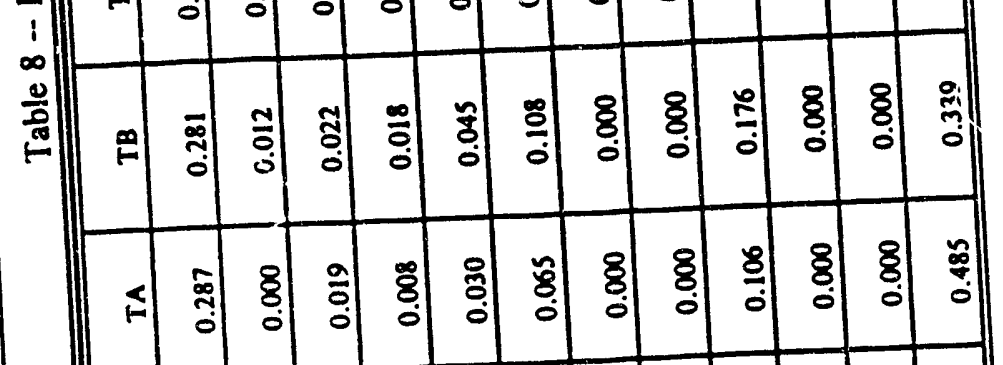

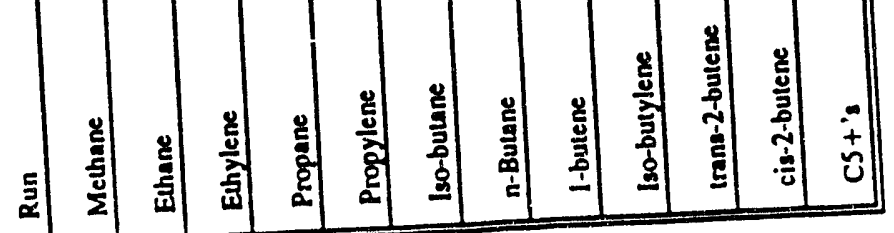




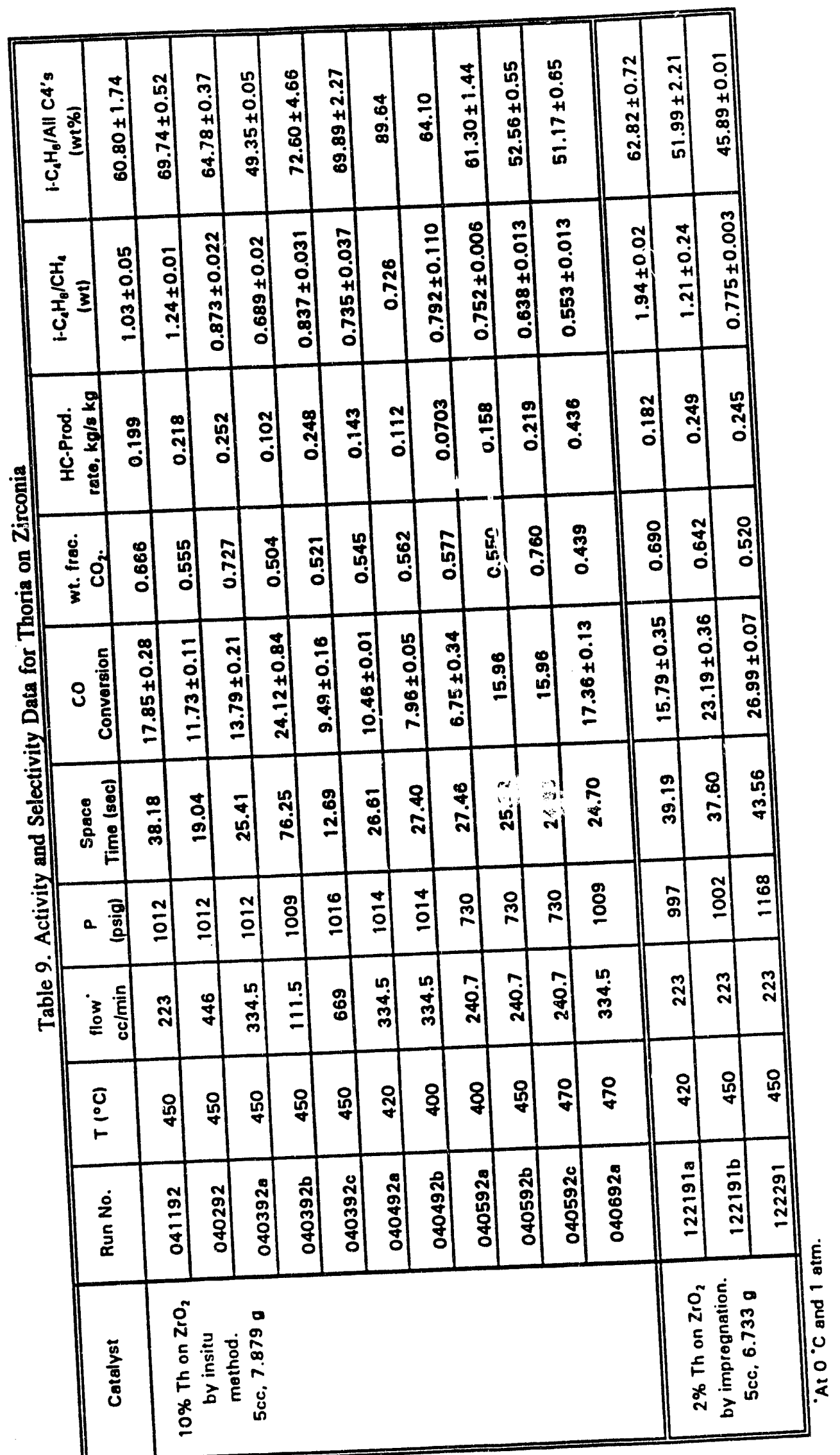


Table 10. Hydrocarbon Distribution for $2 \%$ Th/ $\mathrm{ZO}_{2}$

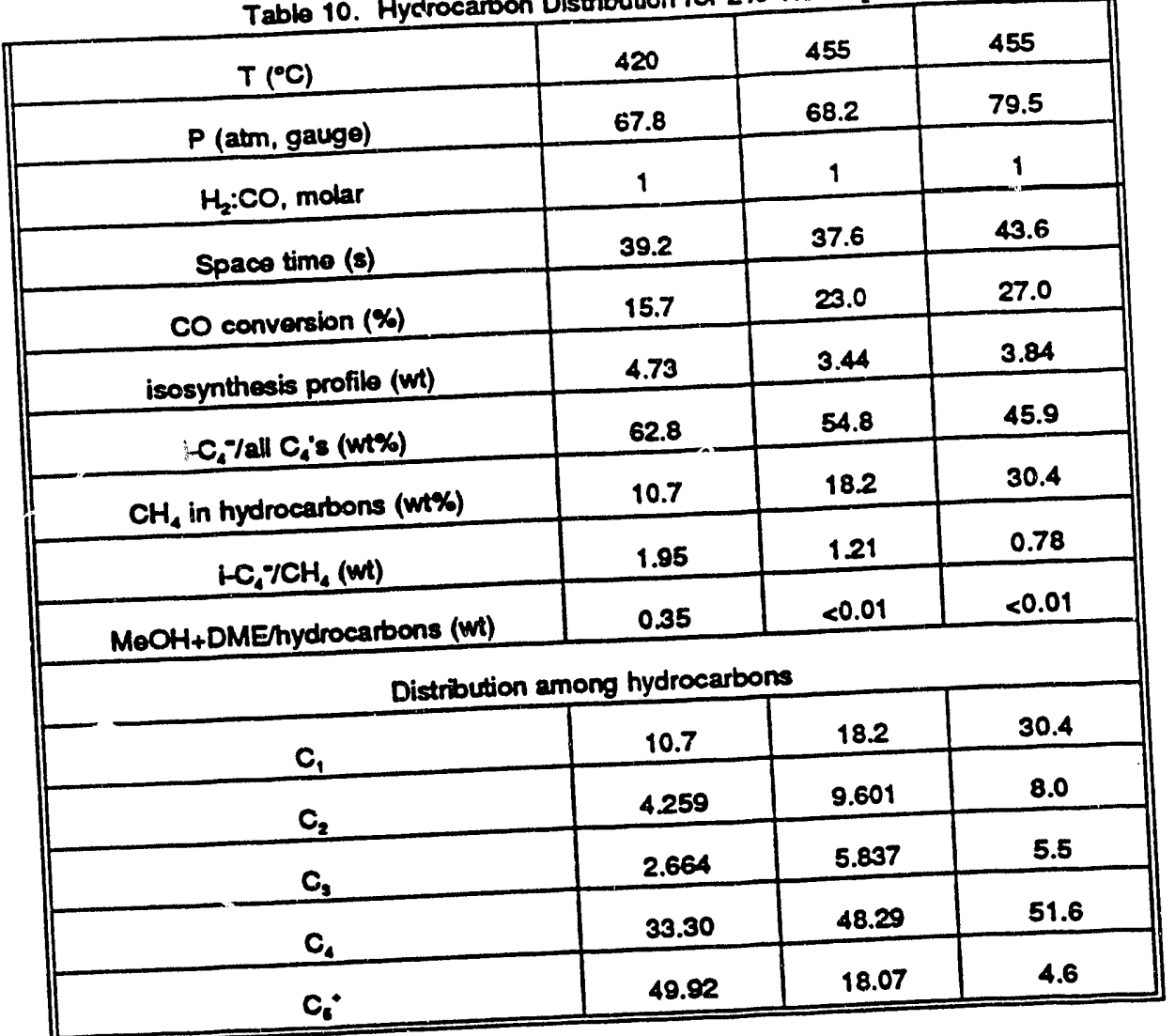



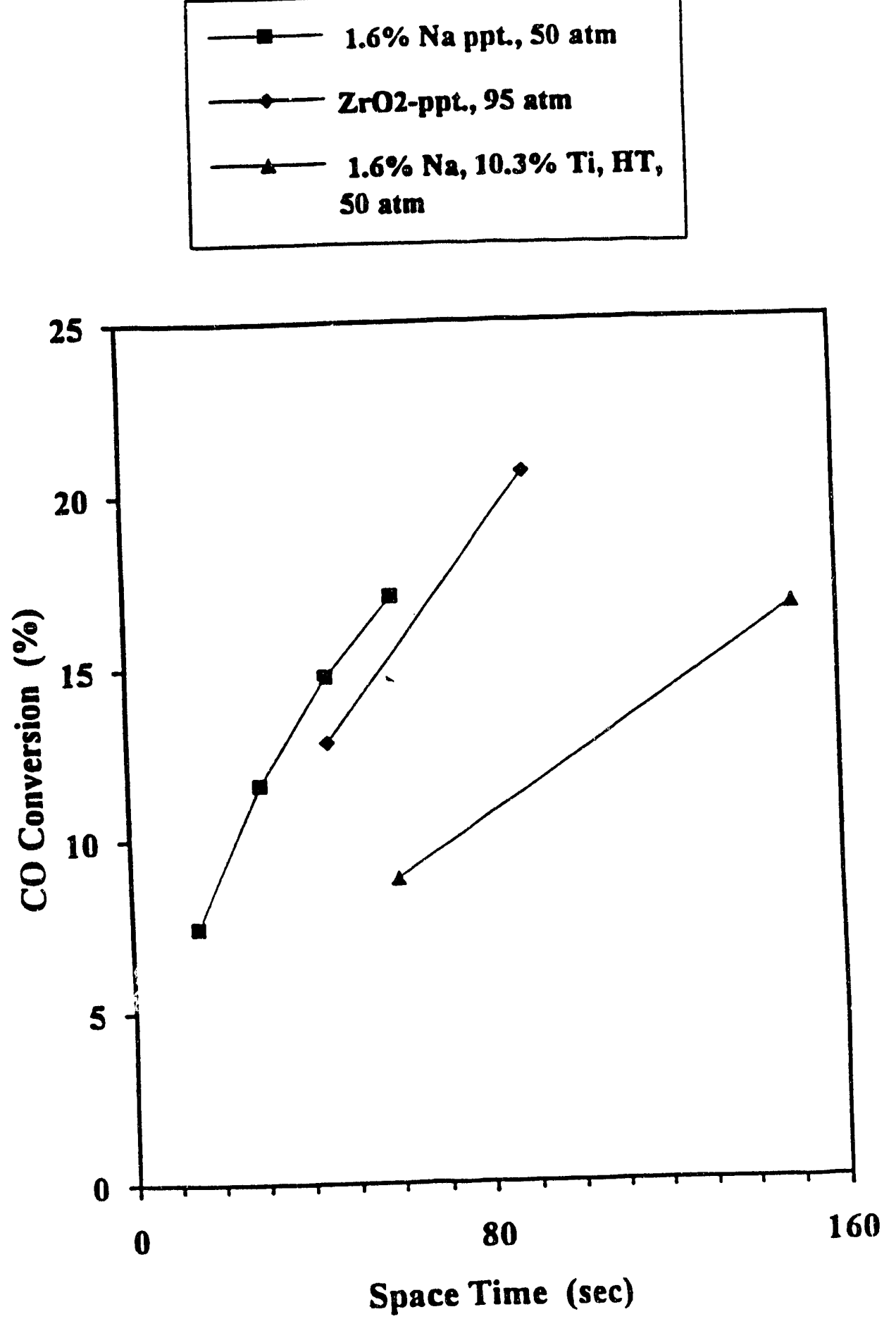

Figure 1. Comparison of Activity at $400^{\circ} \mathrm{C}$ and $1 / 1 \mathrm{CO} / \mathrm{H}_{2}$. 


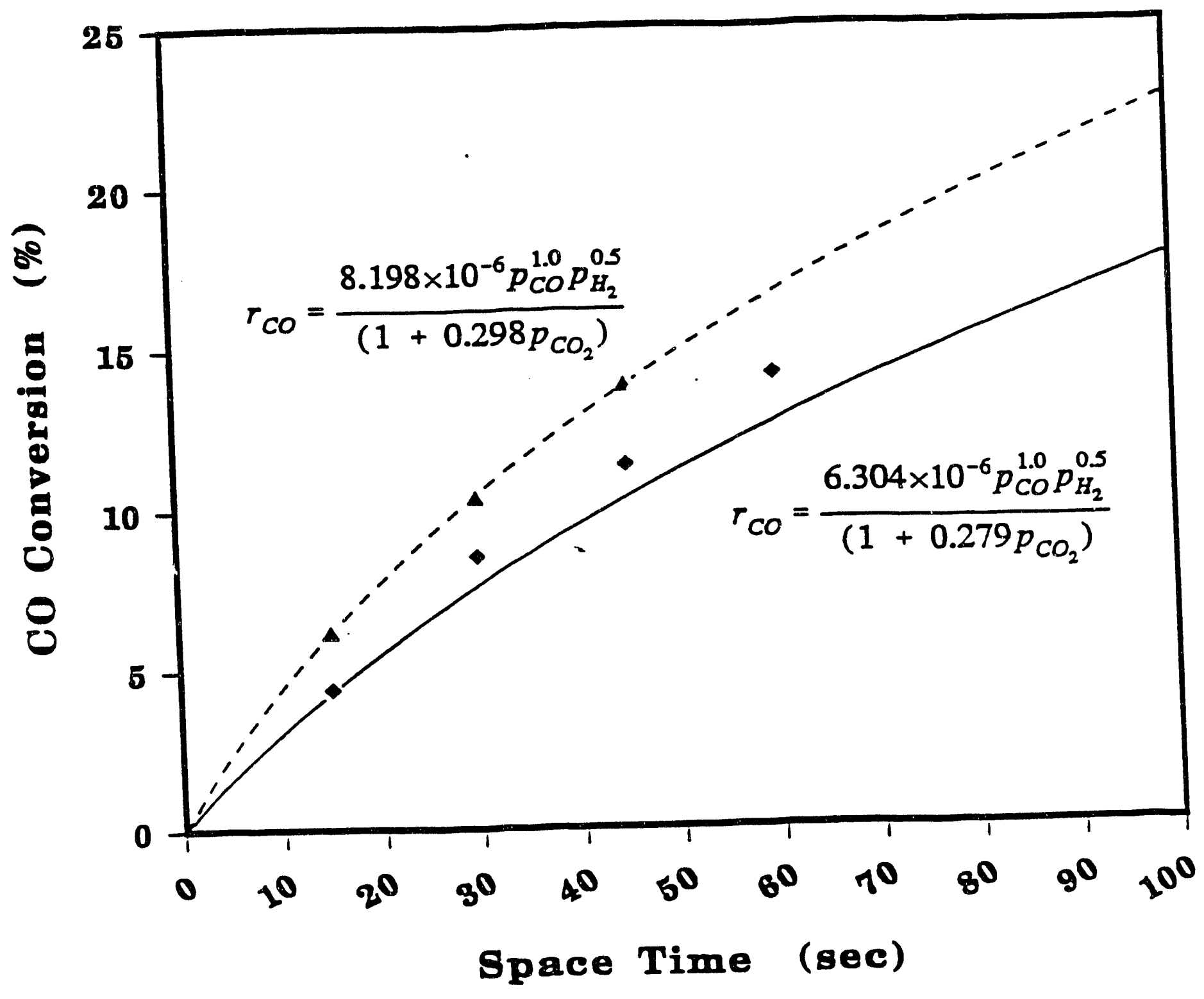

Figure 2. Simulation of $1.6 \% \mathrm{Na}(\Delta)$ and $\mathrm{ZrO}_{2}$ ppt. ( $\left.\bullet\right)$ at $400{ }^{\circ} \mathrm{C}, 95 \mathrm{~atm}$ and $2 / 1$ $\mathrm{CO} / \mathrm{H}_{2}$. Rate is mol/sec* $\mathrm{kg}$-cat. 


$$
\begin{aligned}
& \text { - } 2 \% \text { Th ppt, } 75 \text { atm } \\
& \text { - ZrO2-ppt, } 80 \text { atm } \\
& \longrightarrow 10 \% \mathrm{Th}, \mathrm{AT}, 70 \mathrm{~atm} \\
& \longrightarrow \text { मZrO2-HCl 0.25Si, sol. } \\
& \text { gel., } 70 \text { atm }
\end{aligned}
$$

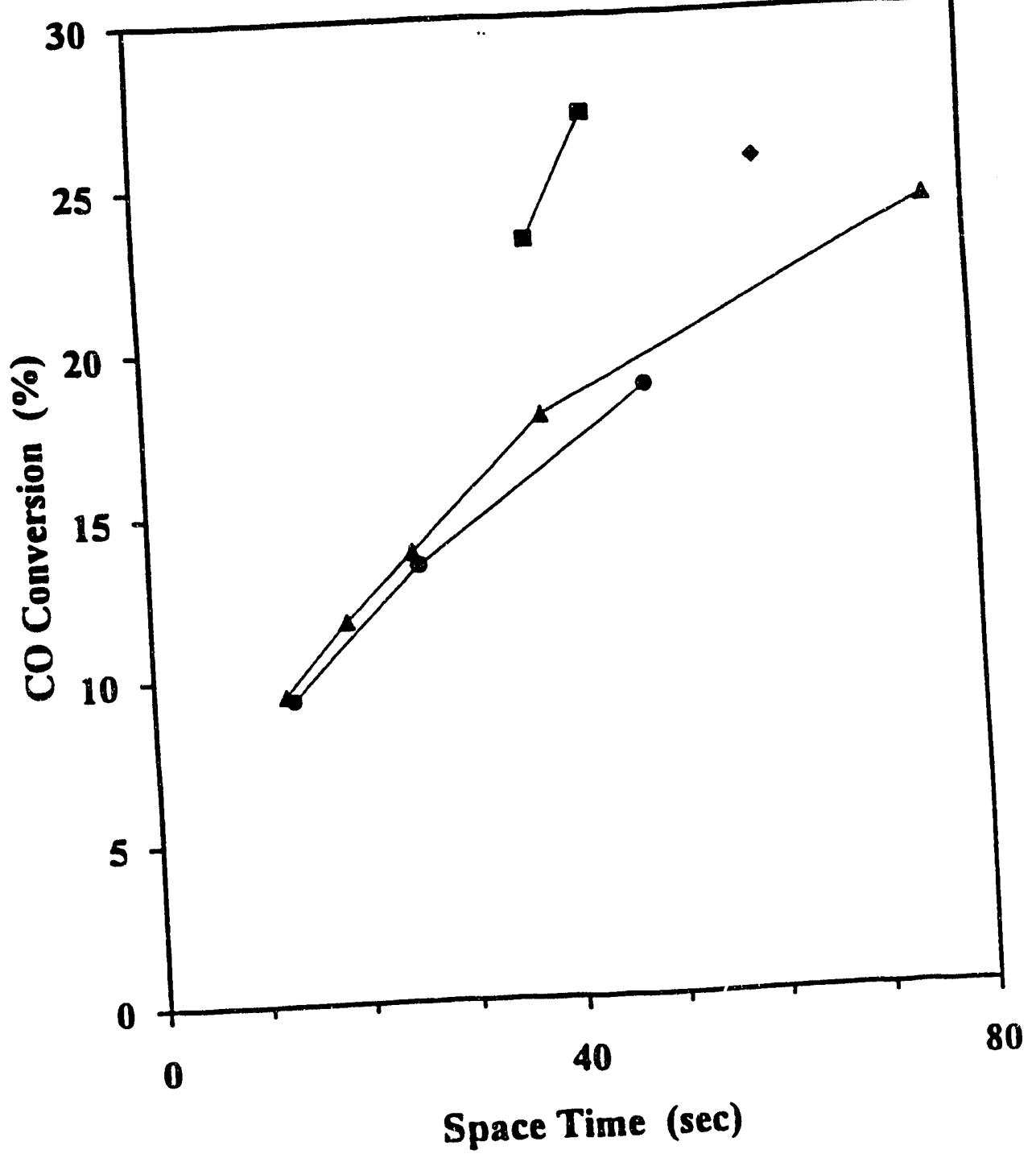

Figure 3. Comparison of Catalytic Activity at $450^{\circ} \mathrm{C}$ and $1 / 1 \mathrm{CO} / \mathrm{H}_{2}$. 

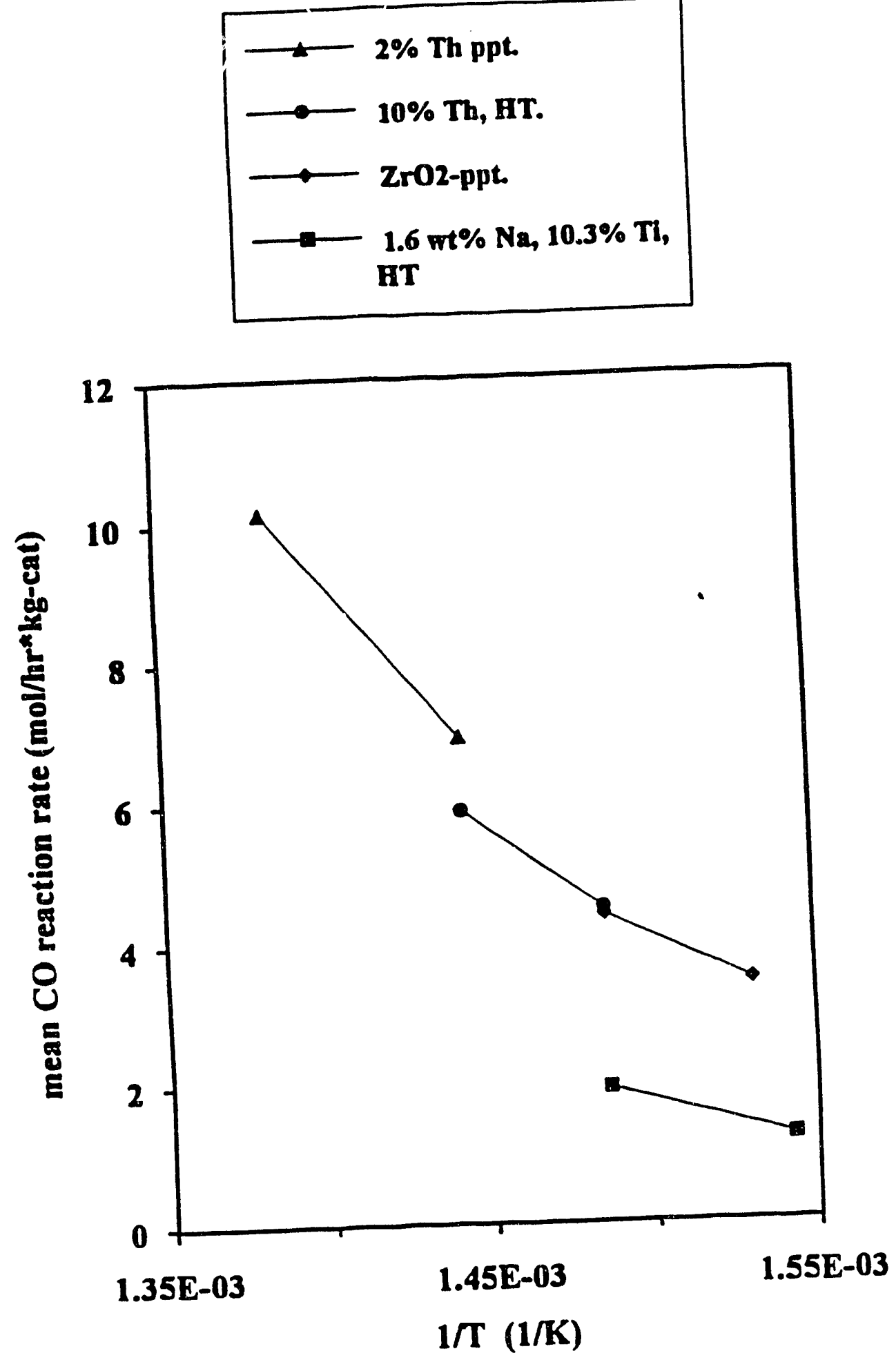

Figure 4. Effect of Temperature on Reaction Rate. 
$\longrightarrow 1.6 \% \mathrm{Na}, \mathrm{ppt}$

$-1.6 \% \mathrm{Na}, 10.3 \% \mathrm{Ti}, \mathrm{HT}$

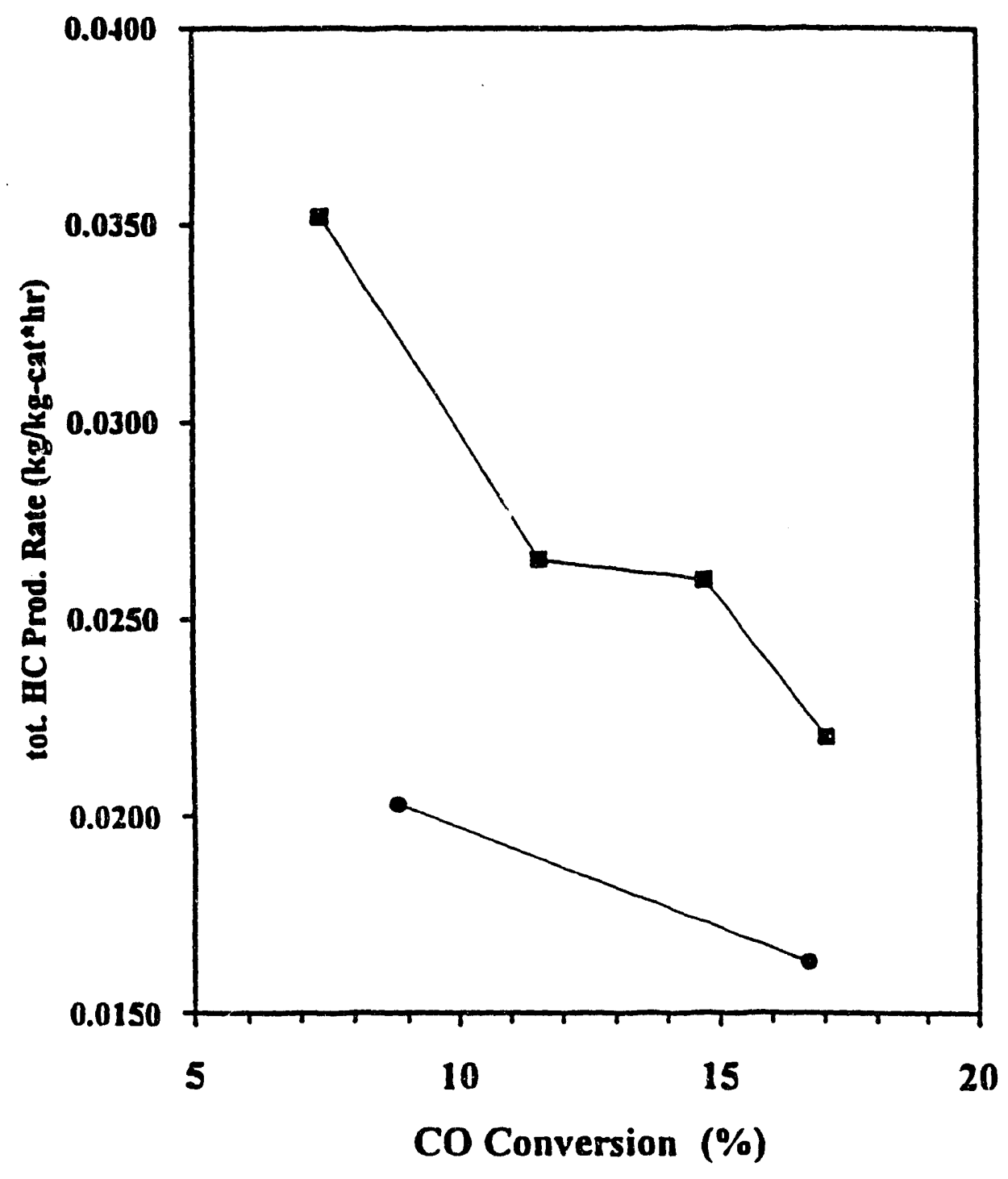

Figure 6. Total Hydrocarbon Production Rate at $400^{\circ} \mathrm{C}, 50$ atm and $1 / 1 \mathrm{CO} / \mathrm{H}_{2}$. 

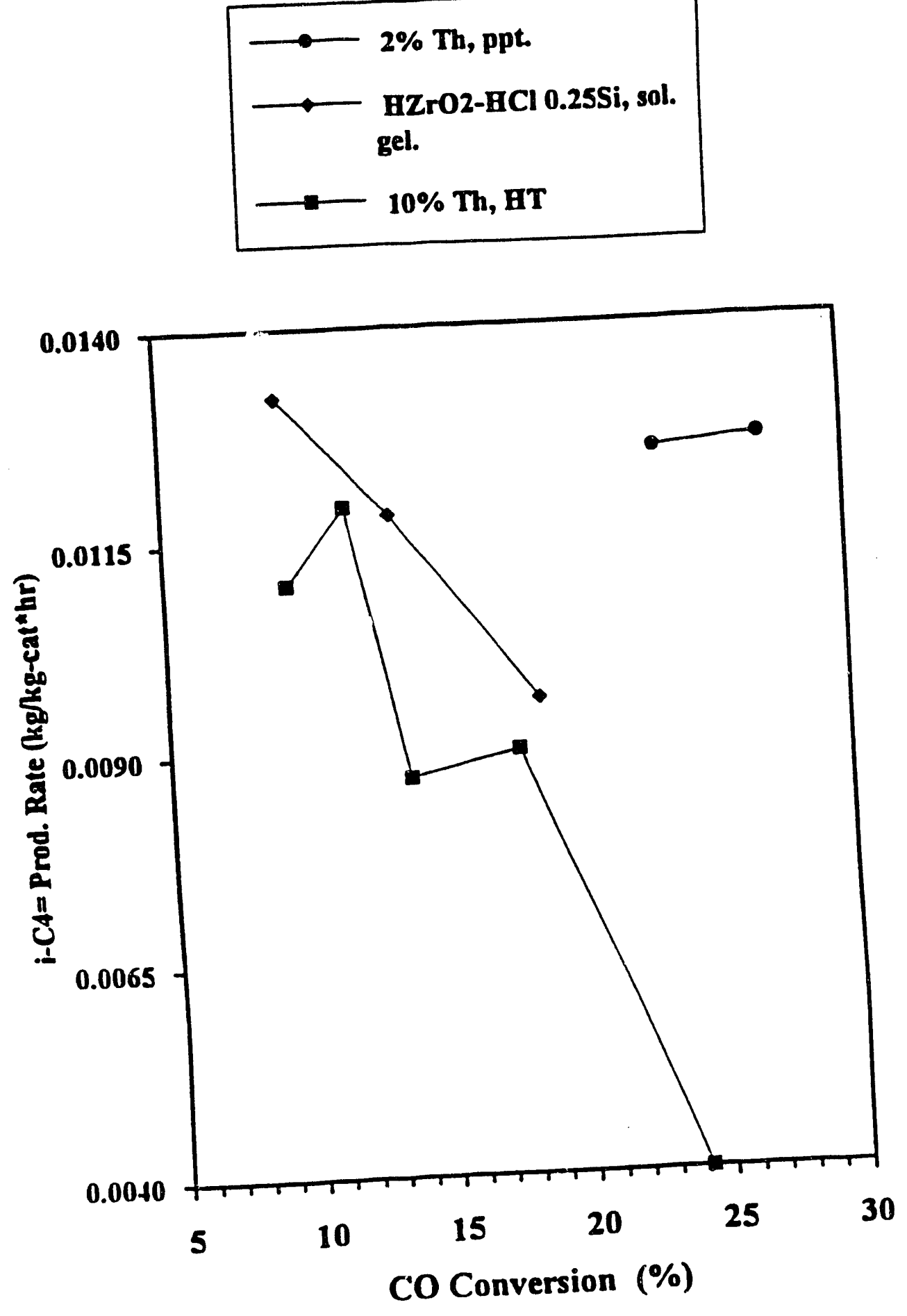

Figure 7. Isobutylene Production Rate at $450^{\circ} \mathrm{C}, 70 \mathrm{~atm}$ and $1 / 1 \mathrm{CO} / \mathrm{H}_{2}$. 

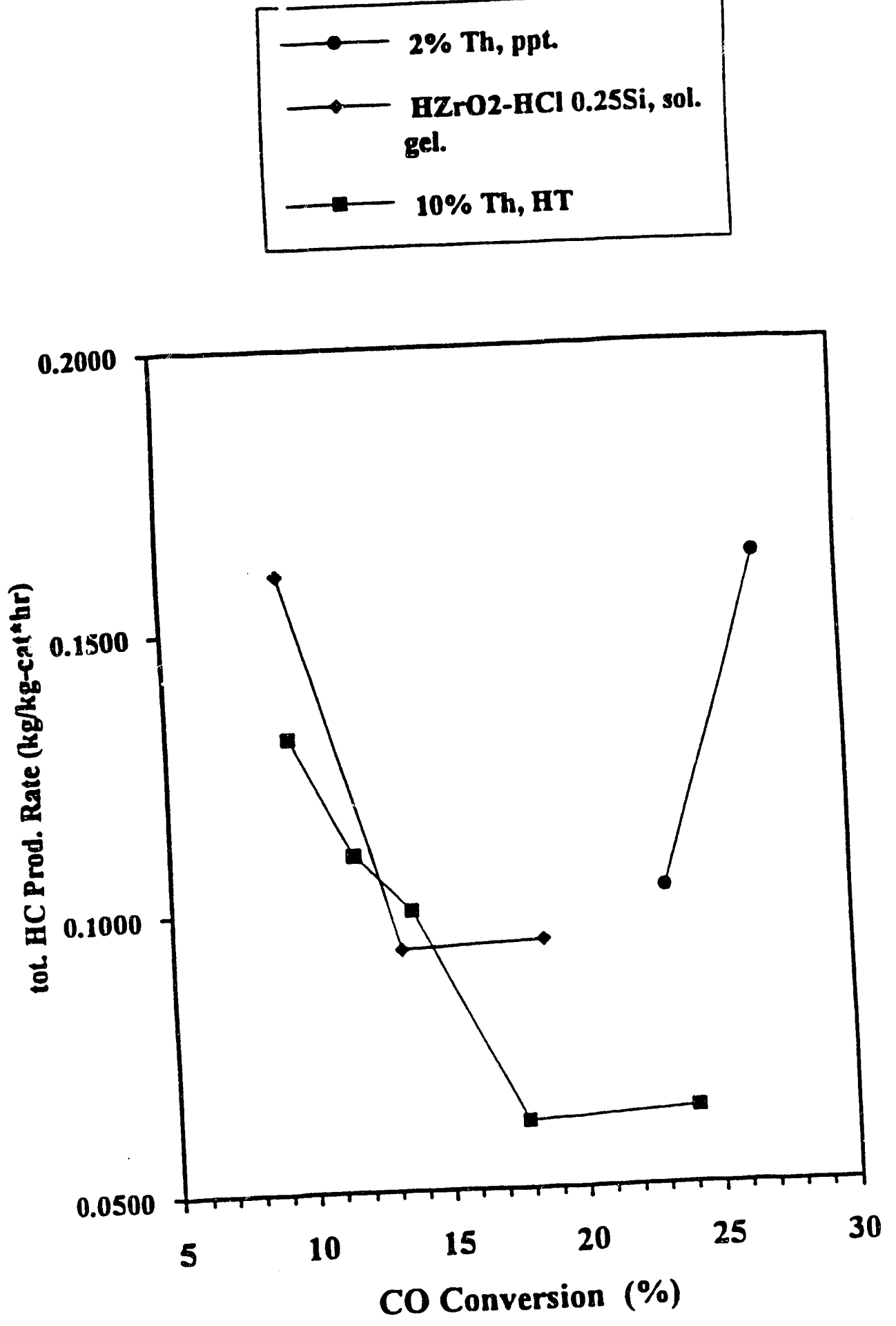

Figure 8. Total Hydrocarbon Production Rate at $450^{\circ} \mathrm{C}, 70$ atm and $1 / 1 \mathrm{CO} / \mathrm{H}_{2}$. 


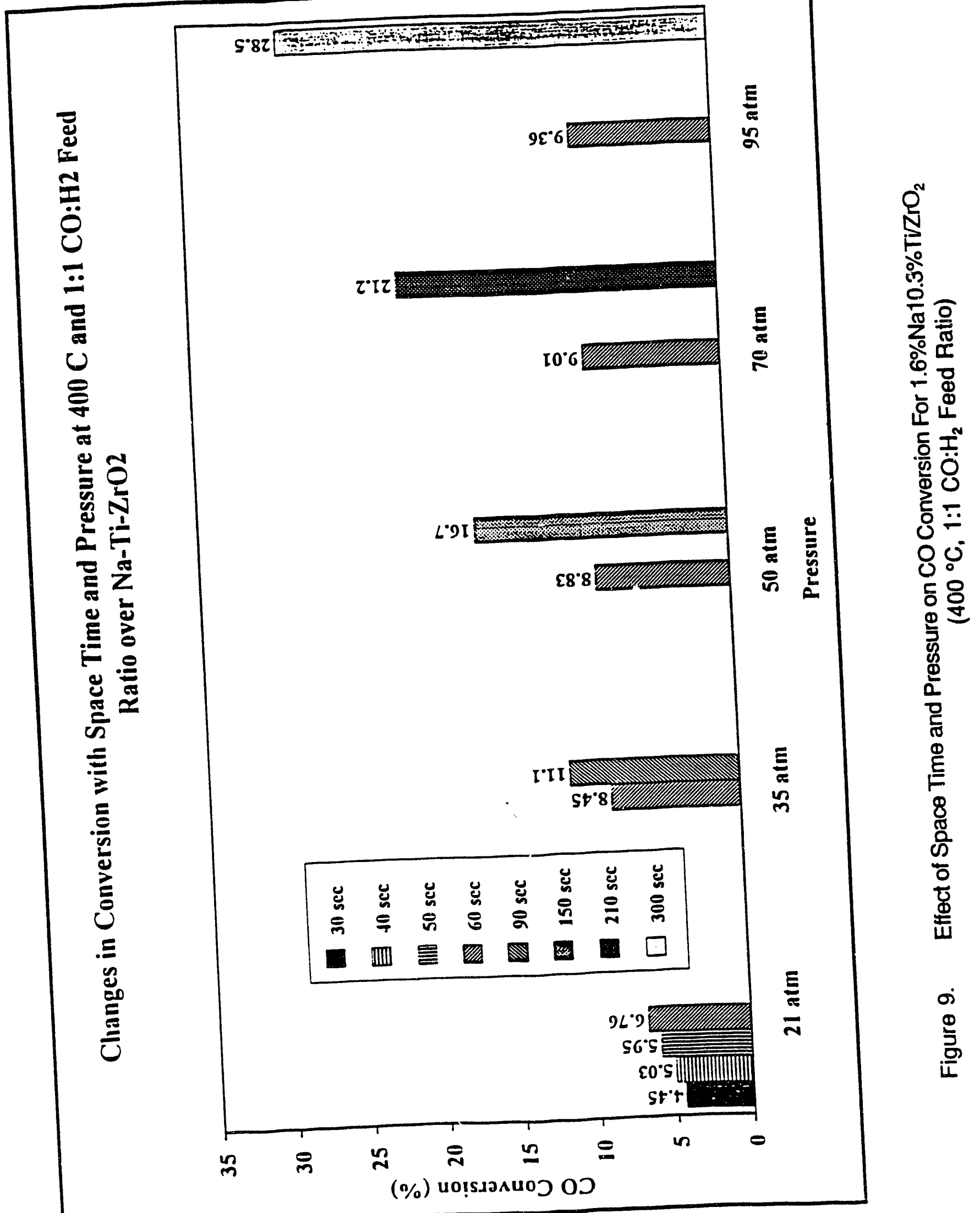




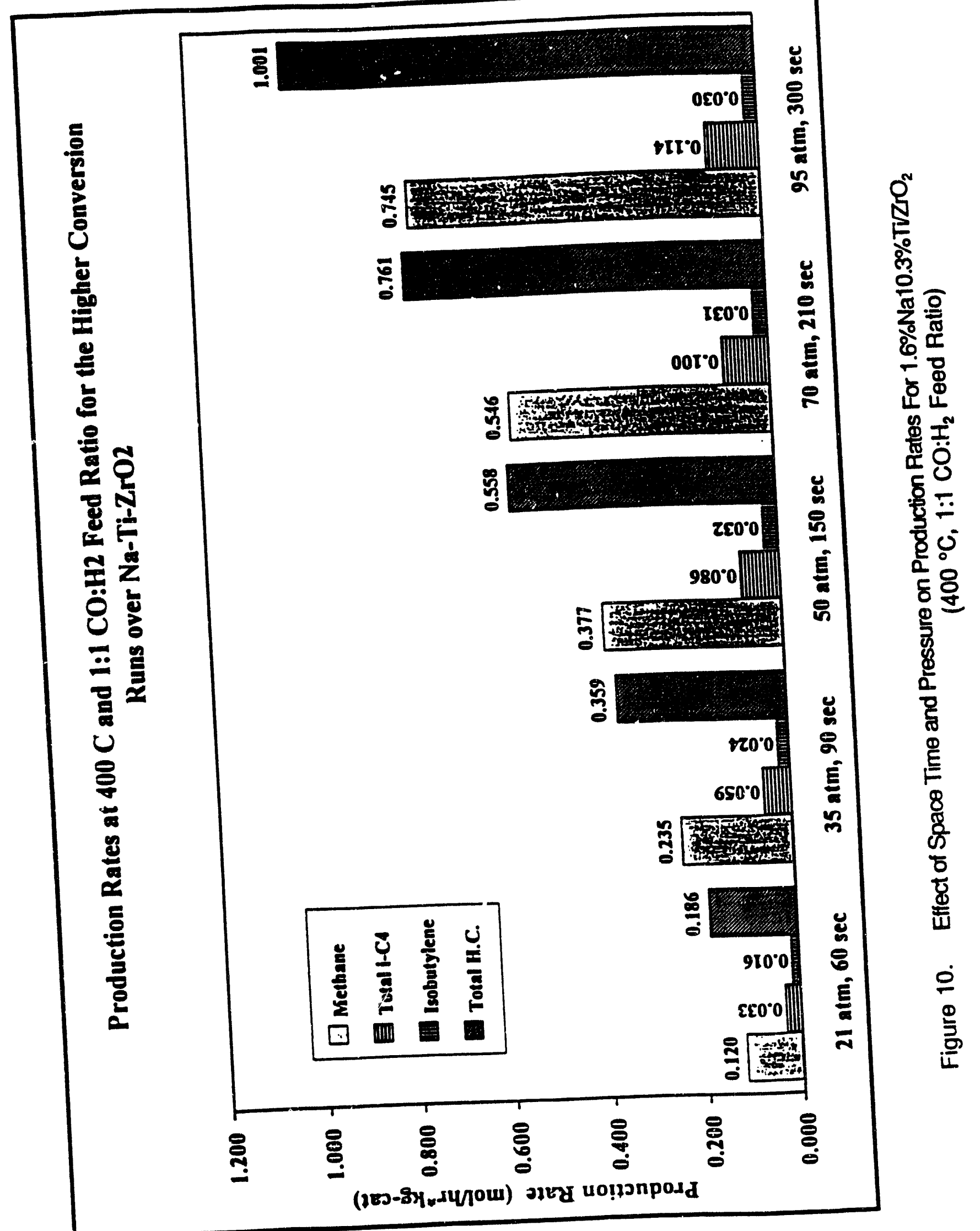




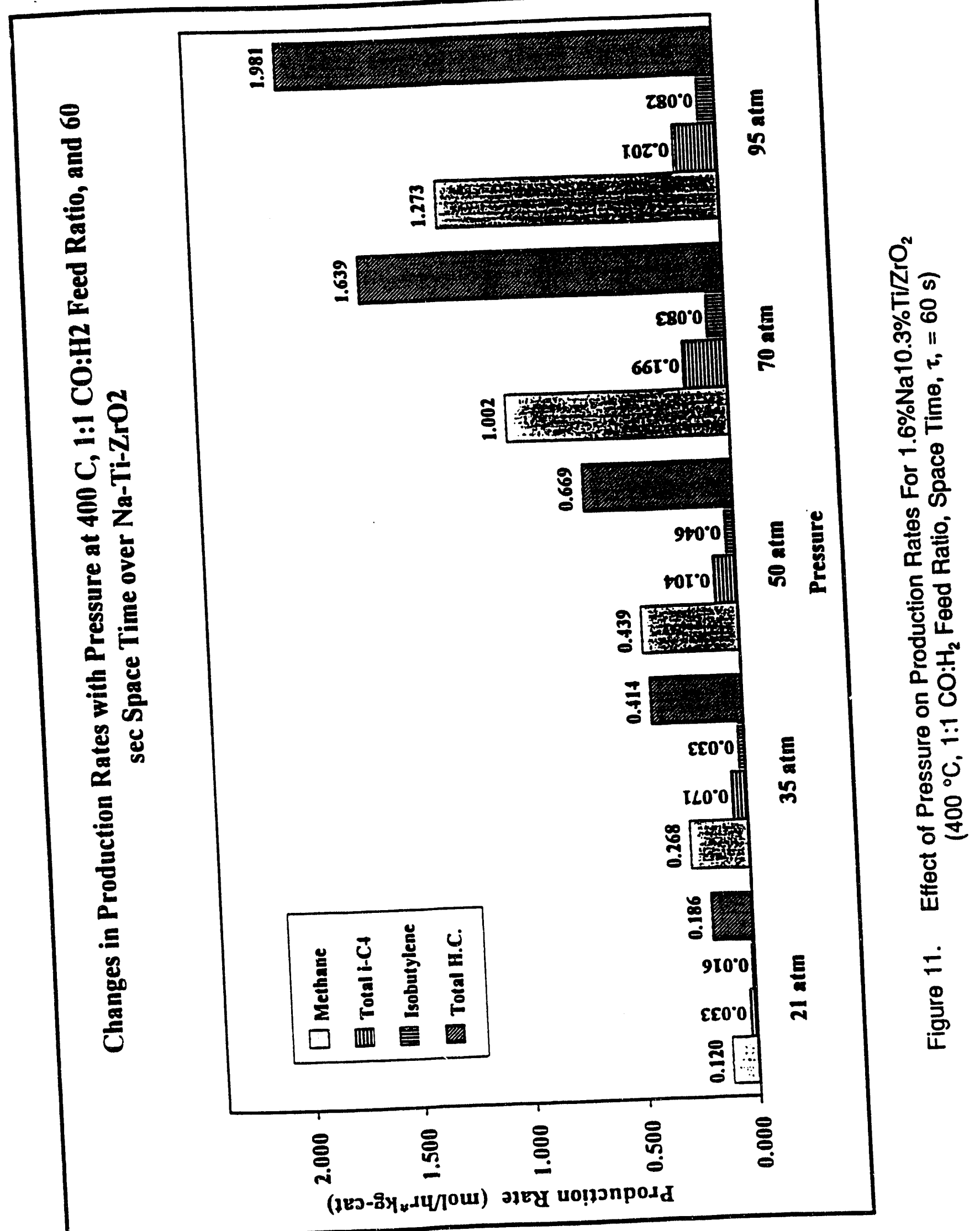




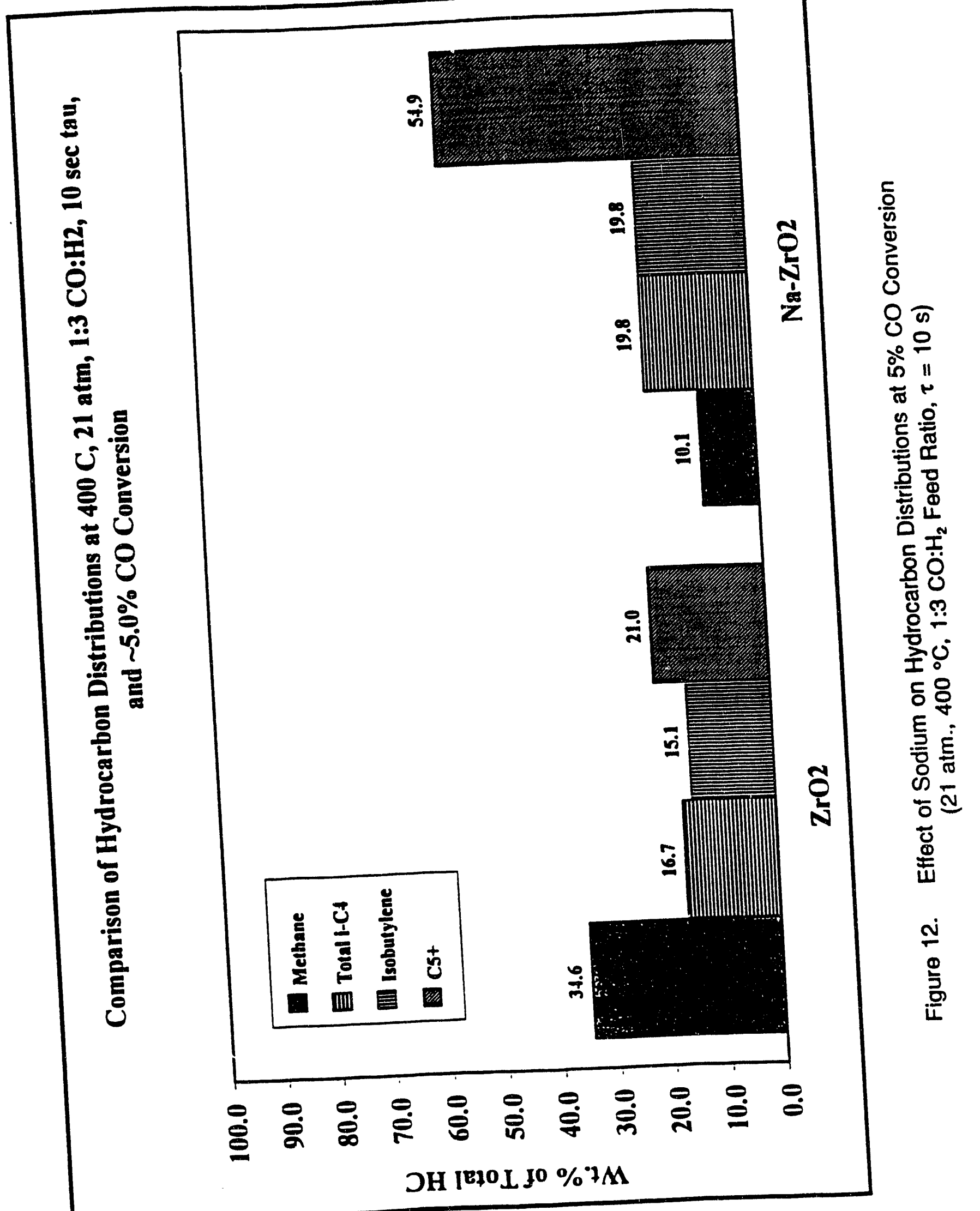




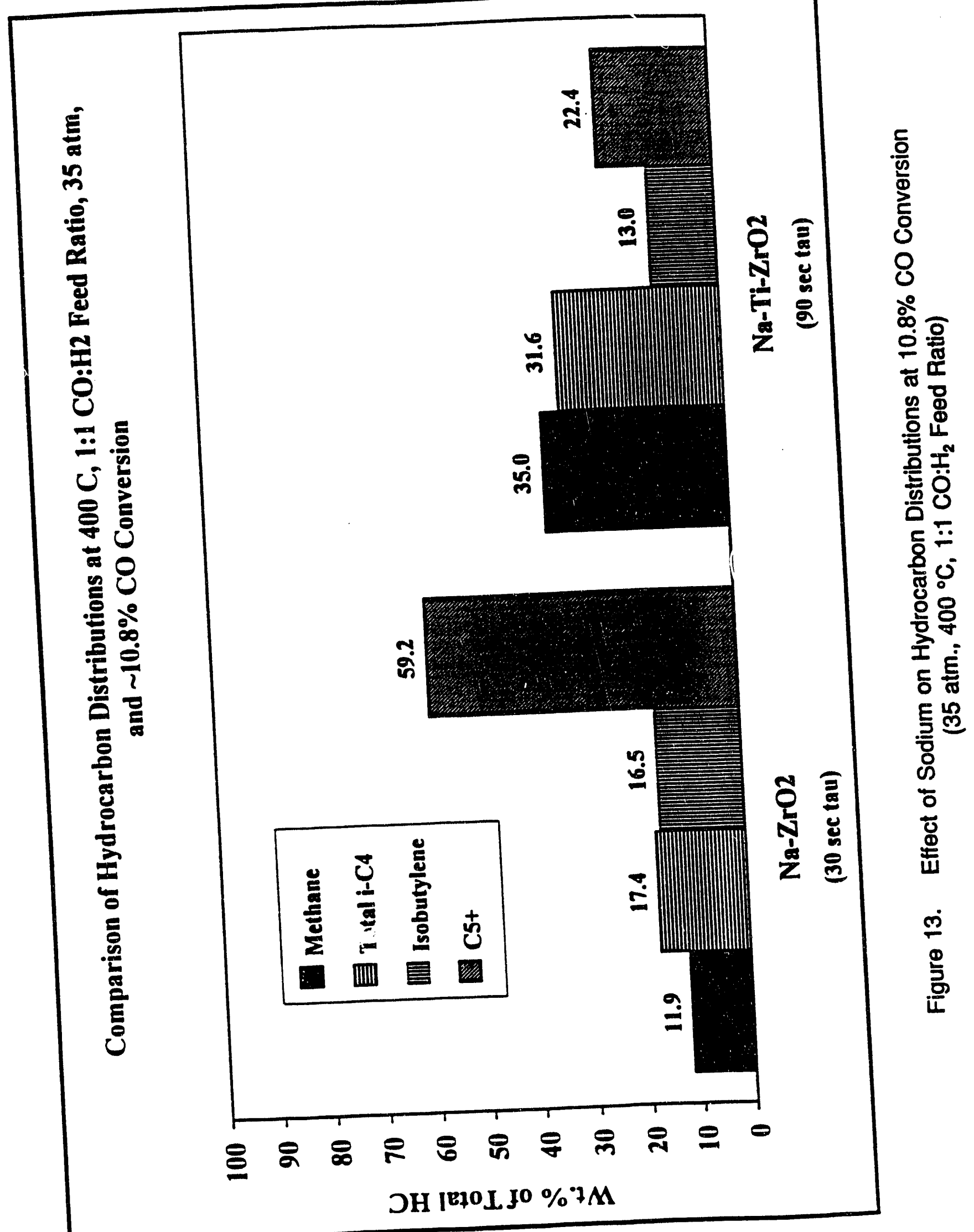



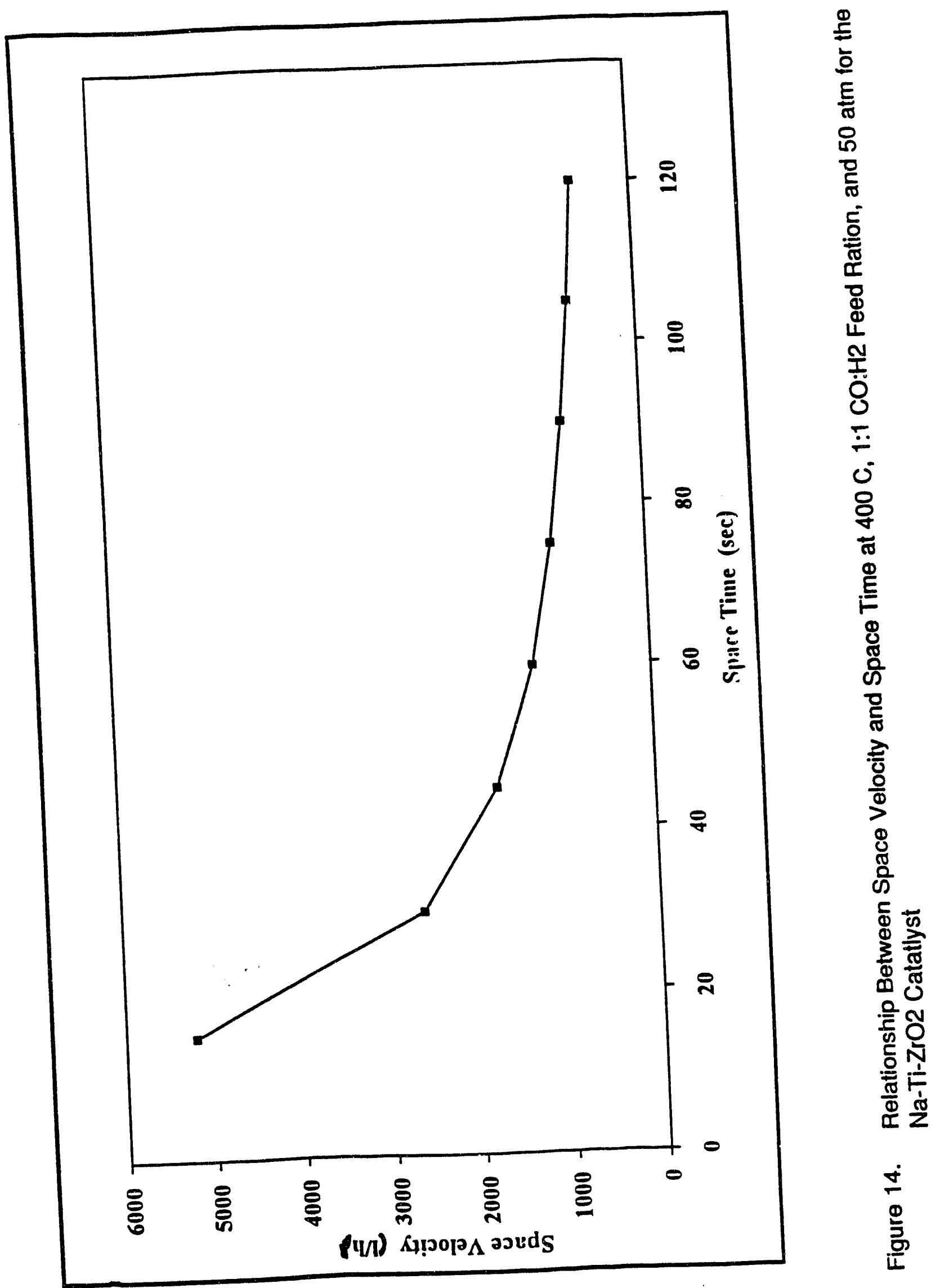


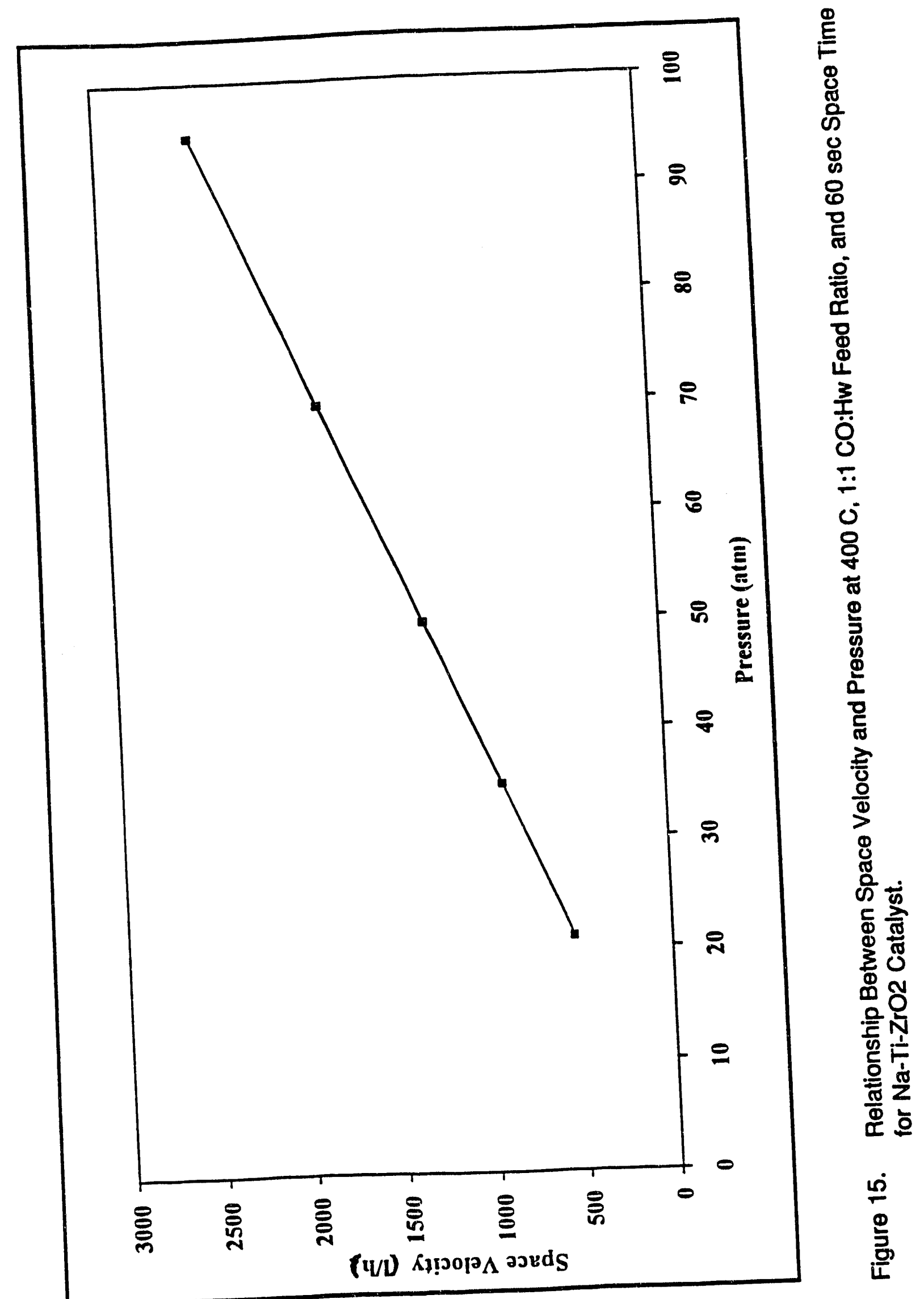




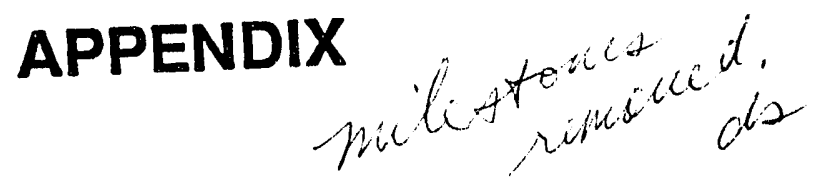




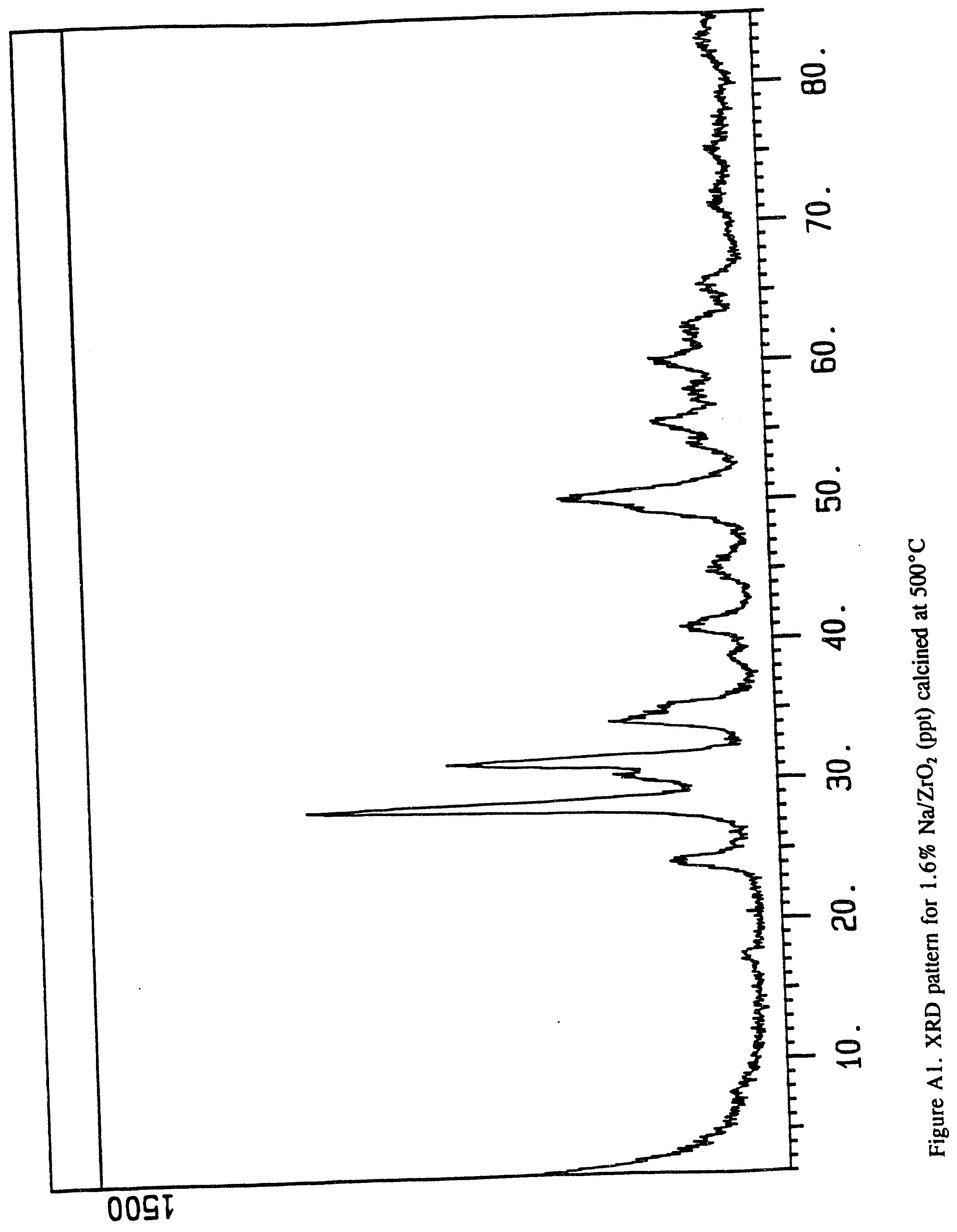




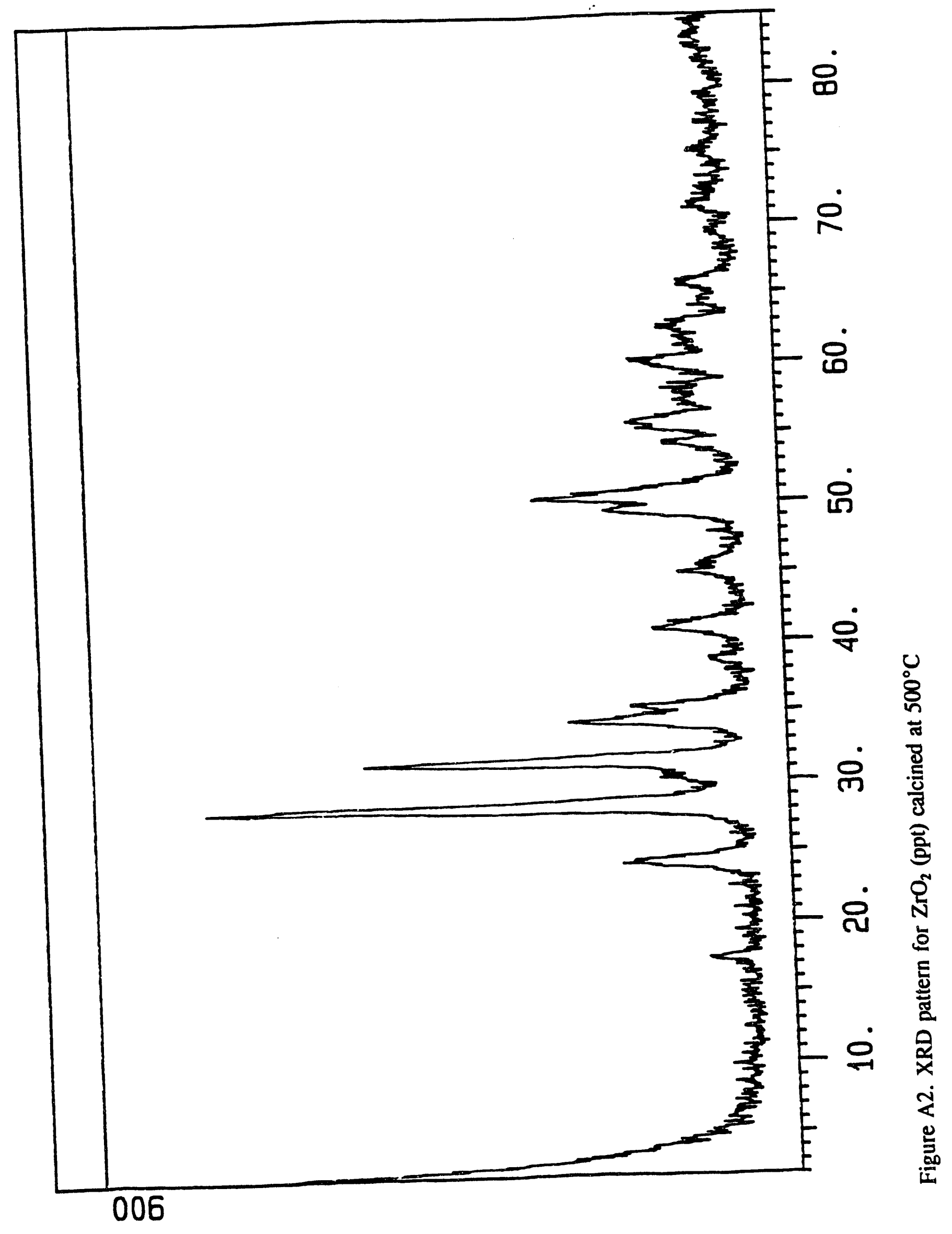




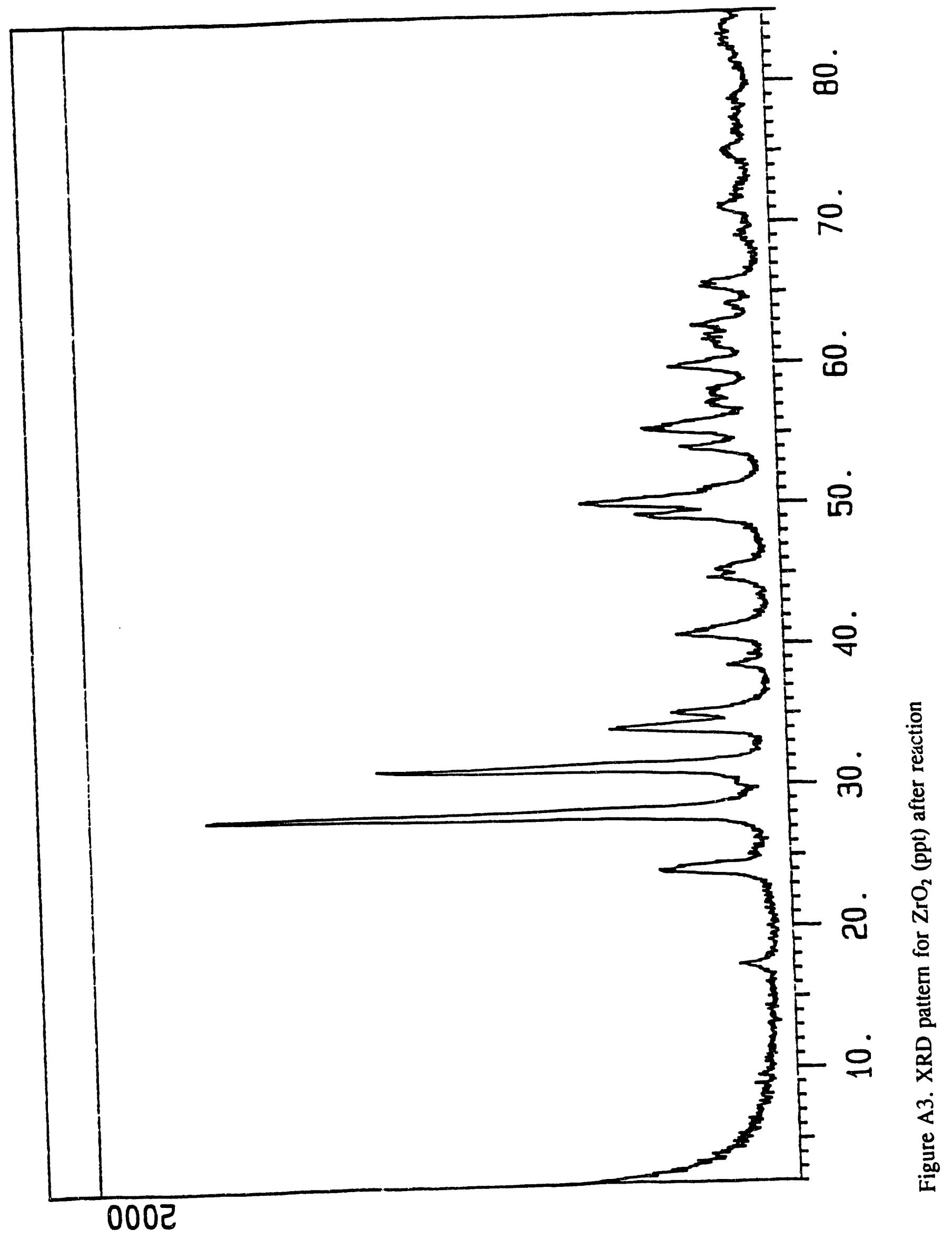




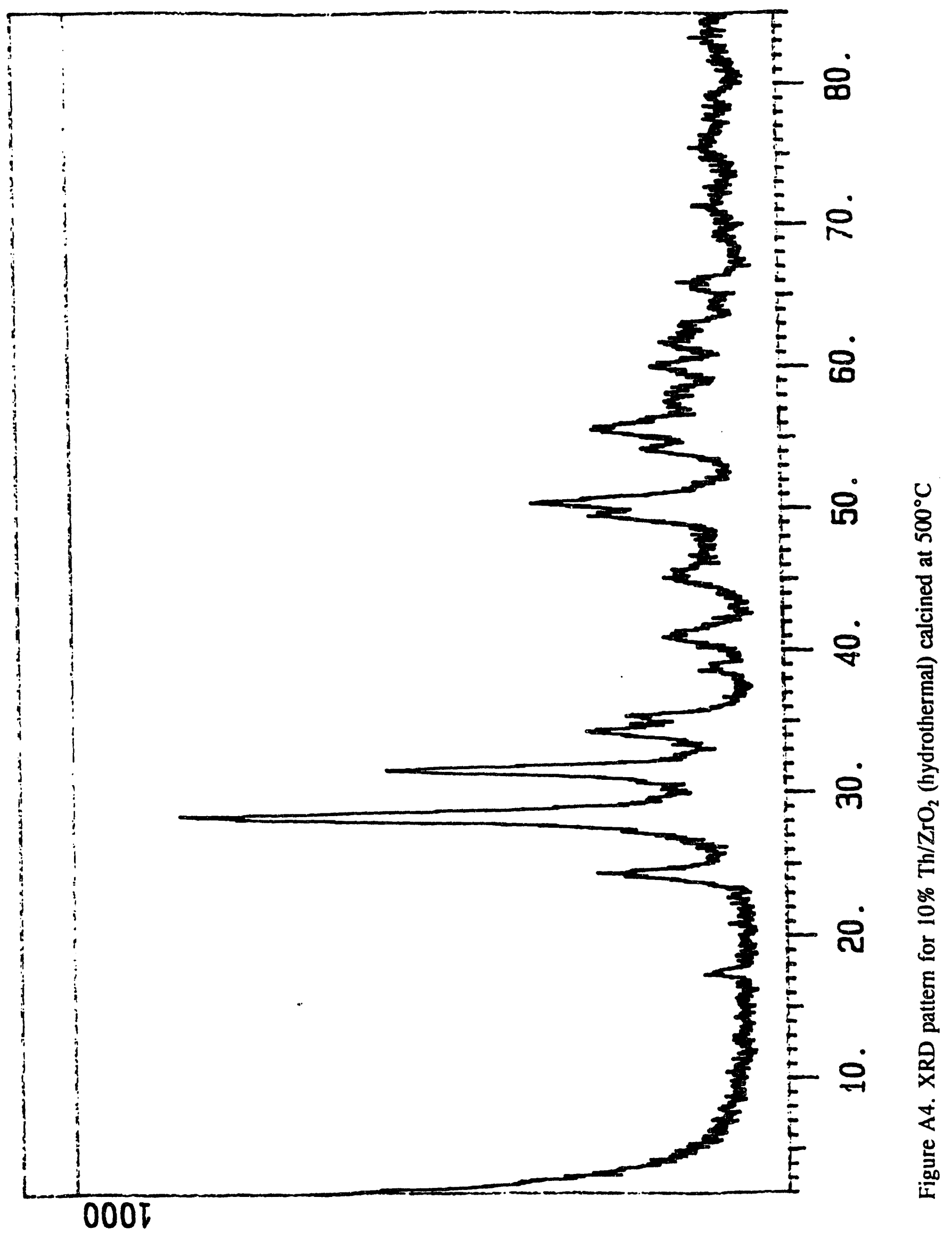




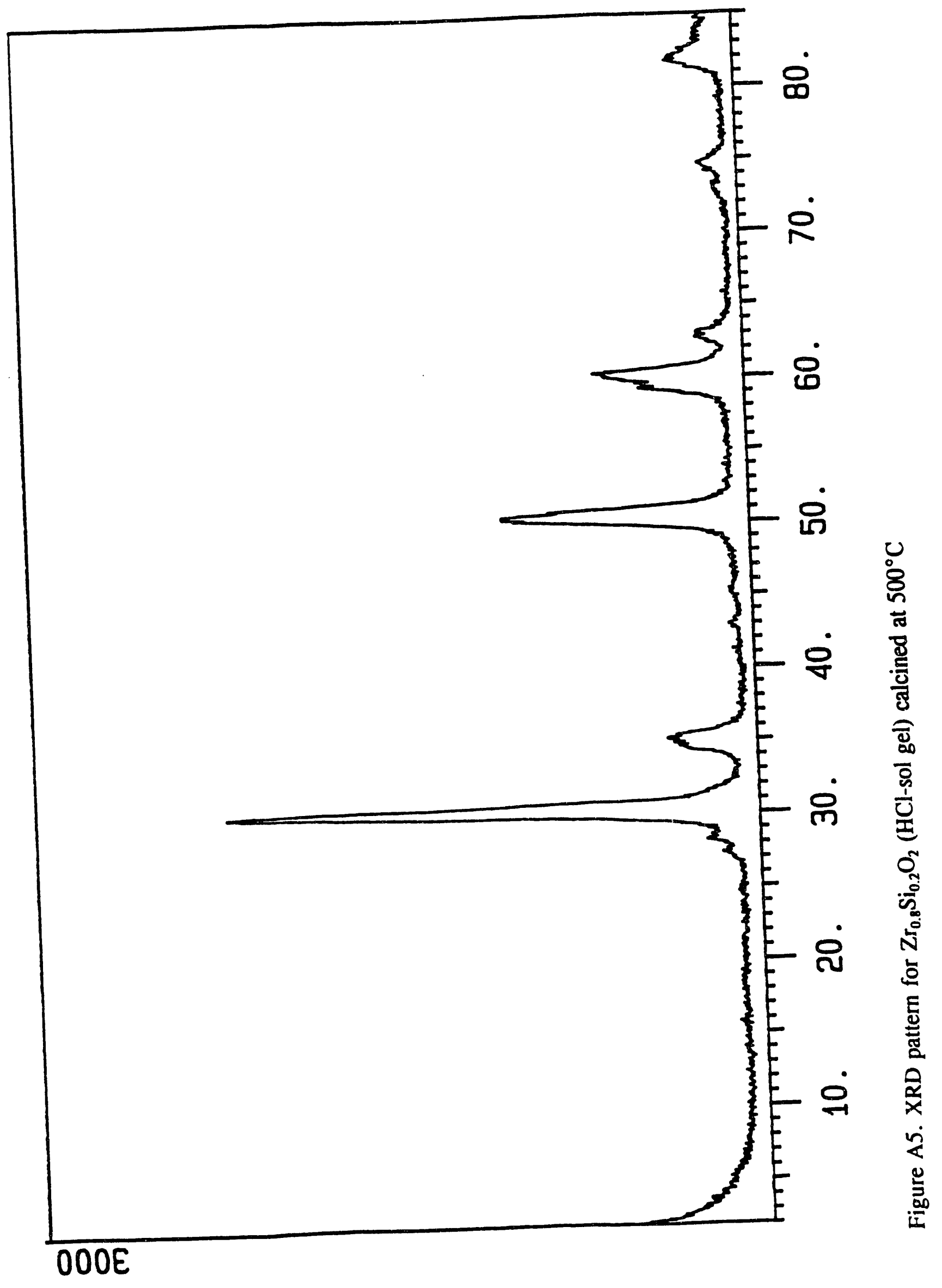




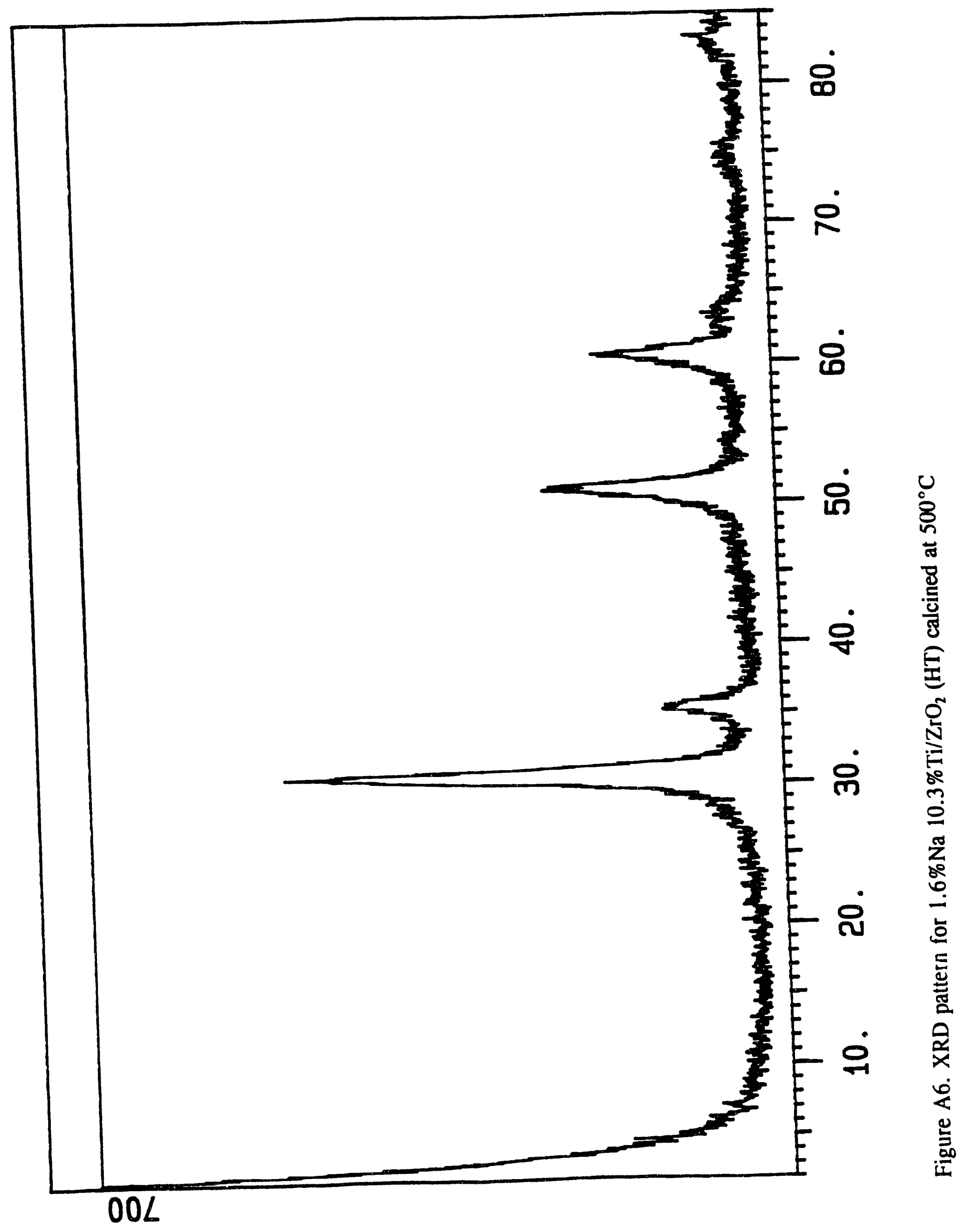




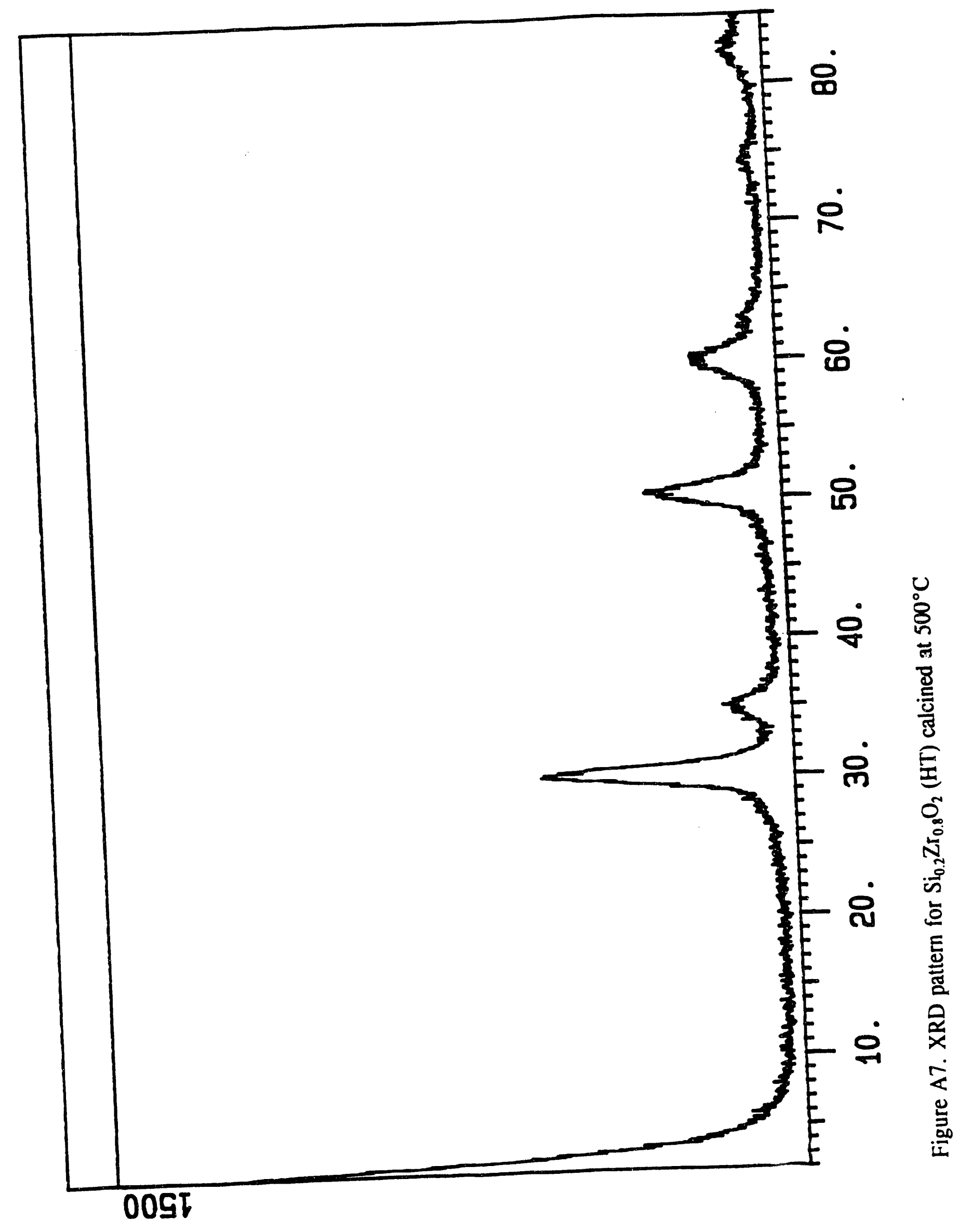




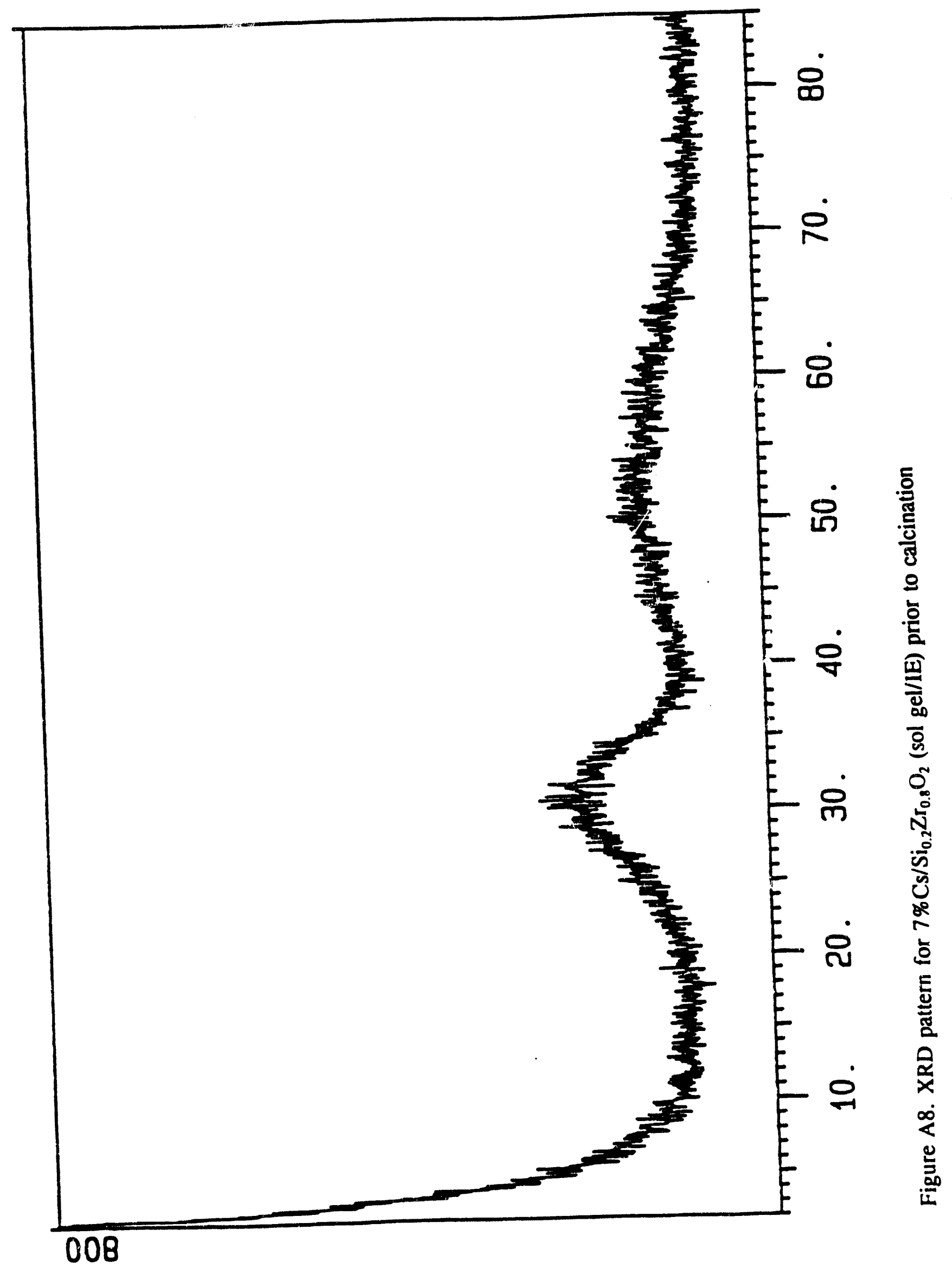




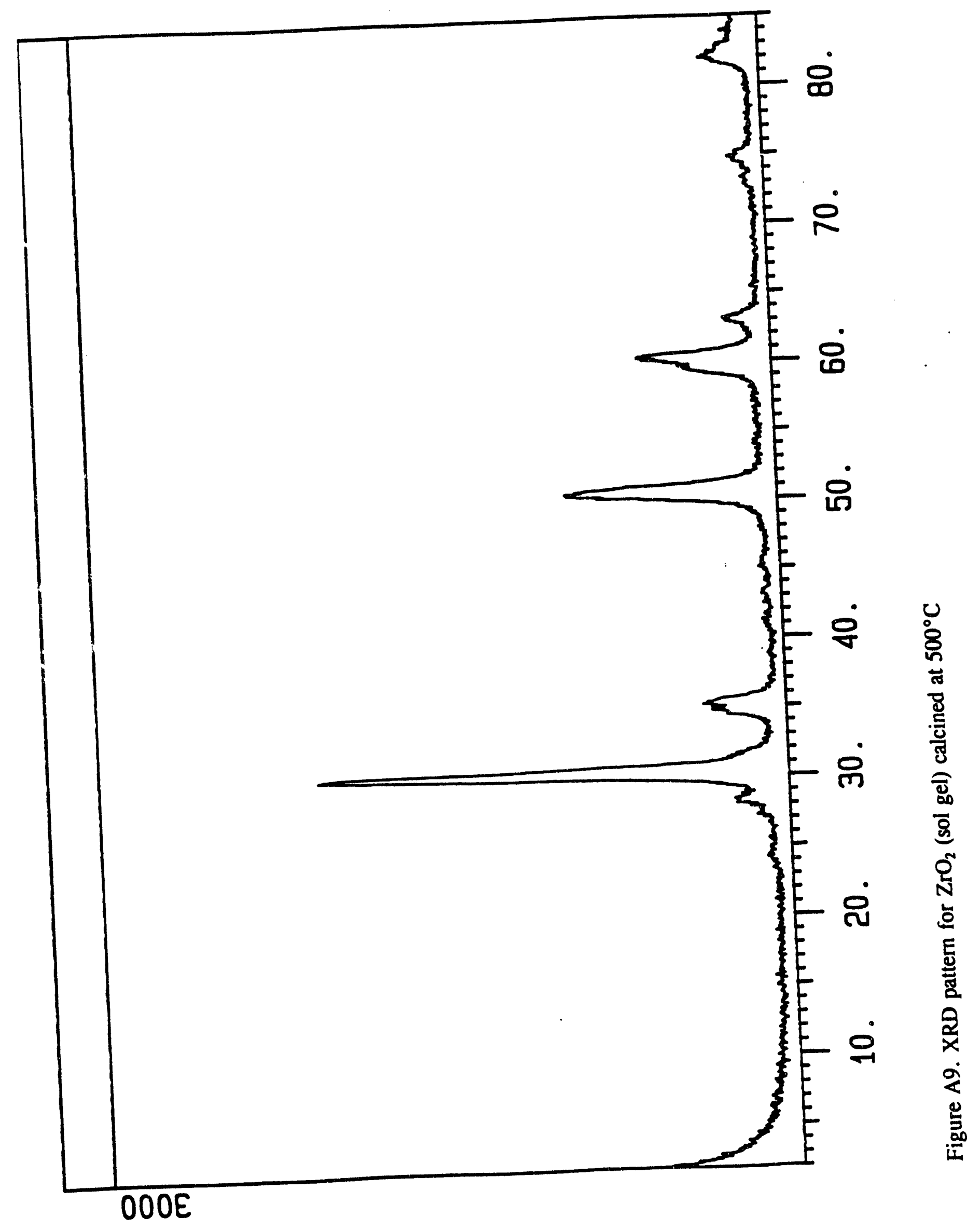



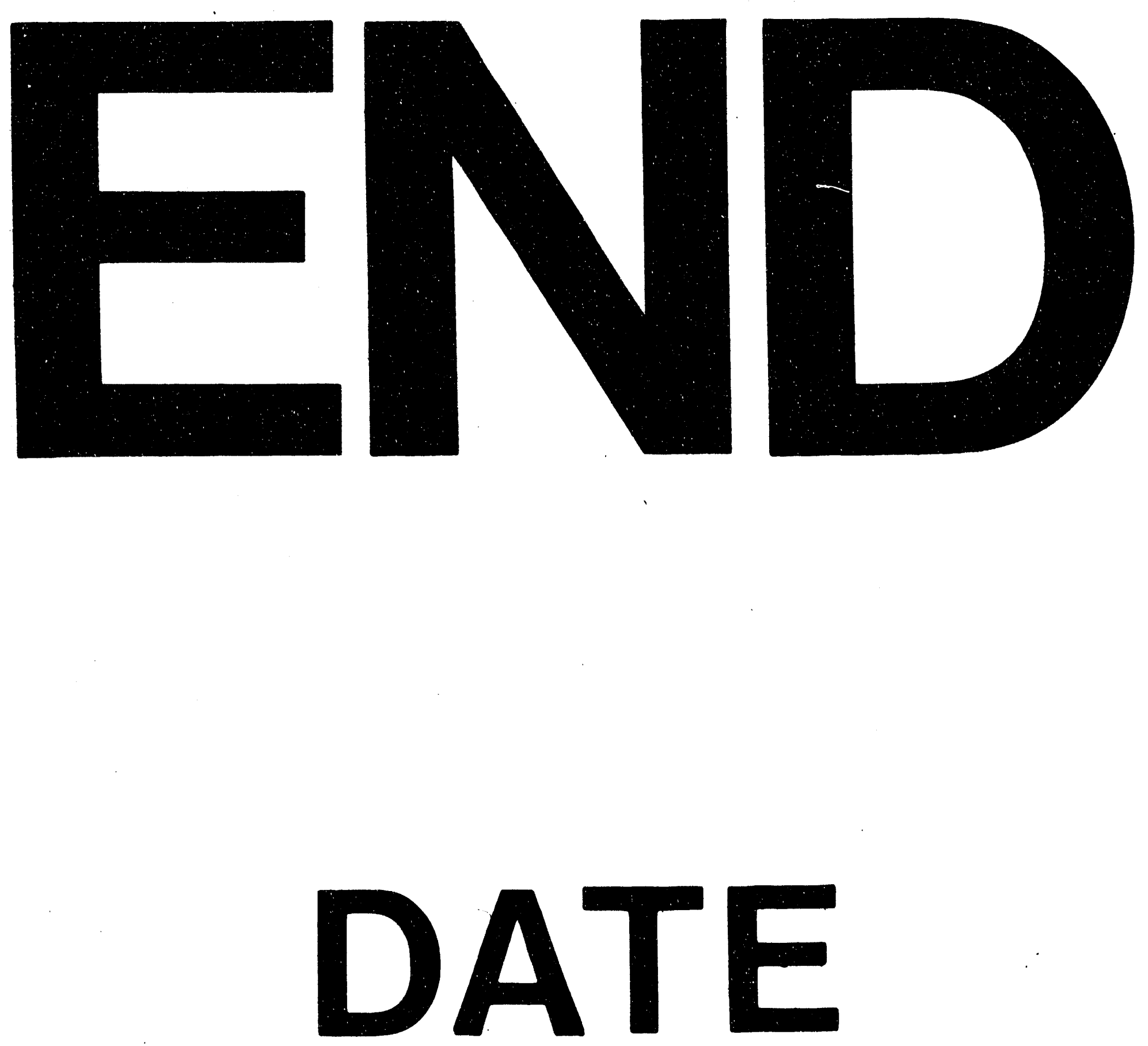

1
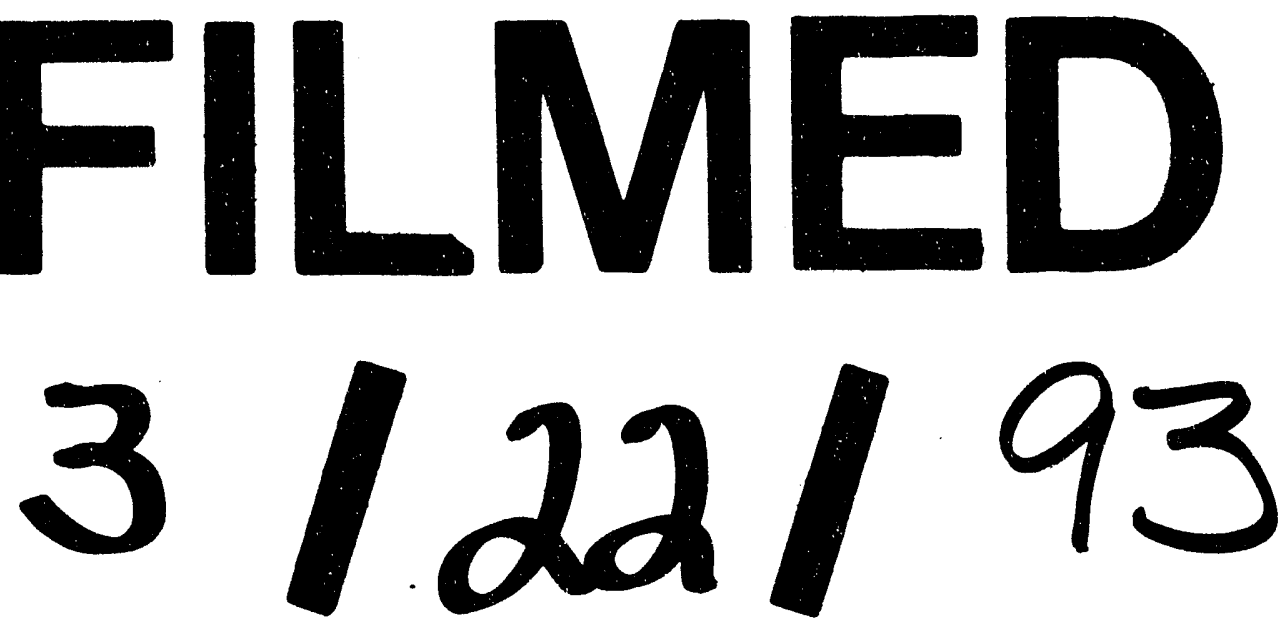
